Pontifícia Universidade Católica do Rio de JANEIRO

\title{
O impacto do Feminismo e Empoderamento Feminino no consumo do mercado erótico
}

\section{Stephanie Bock}

Trabalho de Conclusão de Curso

Centro de Ciências Socials - CCS

Departamento de Administração

Graduação em Administração de Empresas 
Stephanie Bock

\section{O impacto do Feminismo e Empoderamento Feminino no consumo do mercado erótico}

Trabalho de Conclusão de Curso

Trabalho de Conclusão de Curso, apresentado ao programa de graduação em Administração da PUC-Rio como requisito parcial para a obtenção do título de graduação em Administração.

Orientador: João Renato de Souza Coelho Benazzi, Mestre em Administração.

Rio de Janeiro

Junho de 2021. 
"É pelo trabalho que a mulher vem diminuindo a distância que a separava do homem, somente o trabalho poderá garantir-lhe uma independência concreta". (Simone de Beauvoir) 


\section{Agradecimentos}

Gostaria de agradecer aos familiares, amigos e professores que me apoiaram nessa jornada e acreditaram em mim todo esse tempo. Em especial aos grandes alicerces da minha vida, minha mãe e minha avó, por todo amor e carinho, cada palavra positiva de apoio e todos os ensinamentos ao longo da minha criação, ambas são meus exemplos de vida. Ao meu irmão que me ensina todos os dias a ser uma pessoa melhor e a entender o valor de tê-lo como irmão e amigo e ao nosso pai, Vi, pois sem ele nada disso seria possível, obrigada por me apoiar e me proporcionar esta oportunidade. Não há palavras que possam exprimir a importância destes na minha trajetória e de cada palavra e apoio expedidos a mim. Dedico inteiramente cada conquista minha á vocês.

Poderia destacar muitos dos professores e coordenadores que tiveram papéis importantes na minha trajetória, porém destaco alguns que talvez não saibam o quanto sou grata e o tamanho de sua importância nesse processo, como Lea Mara, Sandra Regina e Daniela Vargas pelo apoio quando foi necessário, pois sem ele não teria chegado até aqui. Além destas destaco Barbara Levy e Marco Aurélio que, talvez não saibam, porém foram professores que me relembraram da minha paixão por marketing e reacenderam a minha vontade de seguir este processo.

Agradeço aos demais professores que fizeram parte do meu caminho e me proporcionaram alcance a tanto conhecimento, muitos levarei com grande carinho, e membros do IAG - PUC-Rio, em especial ao Gabriel Lisboa, por toda ajuda ao longo do curso. 


\section{Resumo}

Bock, Stephanie. O impacto do Feminismo e Empoderamento Feminino no consumo do mercado erótico. Rio de Janeiro, 2021. 68 p. Trabalho de Conclusão de Curso - Departamento de Administração. Pontifícia Universidade Católica do Rio de Janeiro.

O comportamento do consumidor possui influências diferentes dadas por fatores distintos. Segundo Kotler e Keller (2006), o comportamento de compra do consumidor é diretamente influenciado por fatores culturais, sociais, pessoais e psicológicos. Com isso, espera-se que haja um entendimento quanto a qual fator as pautas de Feminismo e Empoderamento Feminino pertencem e a forma com a qual influenciam o consumo de produtos eróticos. Tendo em vista o objetivo deste estudo, dado pelo interesse em compreender o impacto do Empoderamento Feminino e Feminismo no consumo de produtos eróticos, foi feita uma pesquisa quantitativa, onde foram analisados o grau de associação de 101 mulheres às pautas mencionadas e a sua inclinação ao consumo de produtos eróticos, bem como dados quanto ao perfil e formas de se conectar com o mercado. Os resultados demonstraram que há uma grande associação das mulheres às pautas aqui estudadas e grande inclinação ao consumo de produtos eróticos, criando uma associação entre o grau de influência dado pelas pautas no âmbito da sexualidade e o comportamento de consumidoras deste mercado.

\section{Palavras-chave}

Mulheres, Empoderamento, Feminismo, Pautas Sociais, Comportamento do Consumidor, Mercado Erótico, Produtos Eróticos. 


\section{Abstract}

Bock, Stephanie. The impact of Feminism and women empowerment in the Erotic Market. Rio de Janeiro, 2021. 68 p. Trabalho de Conclusão de Curso Departamento de Administração. Pontifícia Universidade Católica do Rio de Janeiro.

The consumer behavior has different influences given by diferente factors. According to Kotler and Keller (2006), consumer buying behavior is directly influenced by cultura, social, personal and psychological factors. By that, it is expected that there is an understanding to which fator the Feminism and Women Empowerment guidelines belong and the way in wich They influence the consumption of erotic products. In view of the objective of this study, given the interest in undertanding the impacto $f$ Women Empowerment and Feminismo $n$ the consuption of erotic products, a quantitative survey was carried out Where the degree os association of 101 women to the mentioned guidelines and their inclination to consume erotic products, as well as data on the profile and ways to connect with the Market. The results demonstrate that thera is a Strong association of women with the topics studied and a Strong inclination to consume erotic products, creating na association between the degree of influence given by the guidelines in the contexto os sexuality ante the behavior consumers in this Market.

\section{Key-words}

Women, Empowerment, Feminism, Social Agendas, Consumer Behavior, Erotic Market, Erotic Products. 


\section{Sumário}

1. Introdução 1

1.1. Contexto e problema de estudo 1

1.2. Objetivo do estudo 5

1.3. Objetivos intermediários do estudo 5

1.4. Delimitação e foco do estudo 6

1.5. Relevância do estudo 6

2. Referencial teórico 8

2.1. O Mercado Erótico 8

2.2. Feminismo, Empoderamento e o comportamento do consumidor 9

$\begin{array}{ll}\text { 2.3. Pauta Social como influência de consumido } & 10\end{array}$

2.4. Feminismo e Empoderamento no Brasil 11

$\begin{array}{lr}\text { 3. Metodologia } & 13\end{array}$

3.1. Tipo de pesquisa 13

3.2. Coleta de dados 13

$\begin{array}{ll}\text { 3.2.1. Limitações do método } & 14\end{array}$

4. Apresentação e análise dos resultados 16

4.1. Descrição da amostra 16

4.2. Descrição dos resultados $\quad 27$

4.3. Análise dos resultados 31

5. Conclusões 33

$\begin{array}{ll}\text { Referências Bibliográficas } & 37\end{array}$

$\begin{array}{ll}\text { Anexos } & 41\end{array}$ 


\section{Lista de Gráficos}

Gráfico 1: Relevância de Feminismo e empoderamento 16

Gráfico 2: Associação ao Feminismo e Empoderamento 17

Gráfico 3: Interesse por produtos eróticos 18

Gráfico 4: Nível de propensão a compra de produtos eróticos 18

Gráfico 5: Influências destas pautas no consumo de produtos eróticos 19

Gráfico 6: Quantas experimentaram 20

Gráfico 7: Propensão a utilizar novamente $\quad 20$

Gráfico 8: Interesse em experimentar 21

Gráfico 9: Consumidoras de produtos eróticos $\quad 21$

Gráfico 10: Consumidoras inclinadas a comprar novamente 22

Gráfico 11: Interessadas em comprar pela primeira vez 22

Gráfico 12: Há fatores que inibem a compra? 23

Gráfico 13: Sexualmente ativa ou não como limitação de uso 26

Gráfico 14: Valor destinado a produtos eróticos 26 


\section{Lista de Tabelas}

Tabela 1: Relevância de Feminismo e empoderamento 16

$\begin{array}{ll}\text { Tabela 2: Associação ao Feminismo e Empoderamento } & 17\end{array}$

$\begin{array}{ll}\text { Tabela 3: Interesse por produtos eróticos } & 18\end{array}$

Tabela 4: Nível de propensão a compra de produtos eróticos 19

Tabela 5: Influência destas pautas no consumo de produtos eróticos 20

Tabela 6: Possíveis fatores que inibem compra 23

Tabela 7: Contribuição de empoderamento, feminismo

e produtos eróticos na liberdade sexual 24

Tabela 8: Motivos que levam a compra 24

Tabela 9: Fontes de informação sobre produtos 25

Tabela 10: Pautas predominantes no ambiente social 25

Tabela 11: Idade $\quad 27$

Tabela 12: Estado civil e relacionamento 28

Tabela 13: Grau de escolaridade $\quad 29$

Tabela 14: Tipo de instituição de ensino 29

Tabela 15: Ocupação 30

Tabela 16: Região do Rio de Janeiro 30 


\section{Introdução}

\subsection{Contexto e problema de estudo}

O mercado erótico e o seu alcance vem mudando bastante desde o seu surgimento na década de 60 . Para o entendimento sobre a visão atual é necessário compreender mais a fundo a história e o contexto do surgimento deste mercado. $O$ primeiro dispositivo similar a um vibrador elétrico foi inventado antes mesmo de 1900 para uso em tratamentos médicos. Muitas histórias foram criadas ao redor desta atmosfera e falácias foram sendo propagadas como teorias até ganharem tanta força que hoje chegam a ser levadas como verdade, dentre elas a história dos tratamentos médicos contra histeria de mulheres utilizando vibradores ou estímulos sexuais (BBC News Brasil, 2019).

O surgimento do primeiro local voltado para mercado erótico veio à tona muitos anos depois com desdobramentos relacionados a novidades no setor e até ao pós guerra. Ao se deparar com os vibradores, produtos eróticos e brechas neste mercado, uma alemã muito à frente de seu tempo, demonstrou a imensa possibilidade de se criar um novo e promissor mercado. A mesma utilizou conhecimentos de vida e visões pessoais sobre o papel da mulher e sua sexualidade para lapidar suas ideias sobre o mercado erótico. Ao se deparar com necessidades de outras mulheres e seu conhecimento próprio ela buscou explorar estas possibilidades como forma de estabelecer uma base para seu sustento, tão necessário no pós guerra. (BBC News Brasil, 2019).

O fato é que desde o início, o erotismo na história, sempre esteve mais focado no universo do prazer masculino, onde era explorado principalmente pelo mercado da prostituição. Vale a pena ressaltar que prostituição e mercado de produtos eróticos são vertentes distintas e com foco em consumidores diferentes e muito mais distantes do que se pode imaginar. Esta separação se deu em meados de 1960, onde surgiu, de uma mulher, uma ideia que estava atenta a necessidade de outras mulheres (BBC News Brasil, 2019). 
Desde esta época o mercado foi sendo influenciado pelas mudanças nos comportamentos sociais, como, por exemplo, o impacto dado pela segunda onda do feminismo em 1970. Este movimento é de suma importância para o entendimento dos desdobramentos na história, visto que até hoje os movimentos feministas geram impactos diretos na forma de visão dos consumidores quanto aos produtos e no consumo do mercado adulto. Entende-se desta forma, pois a modificação das necessidades e interesses dados pelas pautas sociais, como a do feminismo, despertam a modificação das necessidades do público e, com isso, os produtos deste mercado necessitam acompanhar com maior assiduidade para que incitem o consumo destes novos nichos (Associação Brasileira de Empresas do Mercado Erótico - ABEME, 2019).

Vale ressaltar que feminismo e empoderamento feminino, embora façam parte do mesmo universo e estejam presentes dentro do mesmo contexto, são vistos de formas razoavelmente diferentes. As características de cada um impactam o público de maneiras não necessariamente iguais o que acarreta em respostas diferentes relacionadas a sociedade e as mulheres caracterizando um aumento da sua adesão ou resistência ao longo da história. No contexto desta época ocorreu, de encontro aos movimentos feministas, resistência masculina a estes movimentos. Foi neste período que surgiram ideologias machistas sobre o feminismo, com o intuito de desmerecer e até coibir o aumento de adeptos ao movimento. Dentro destas ideologias surgiram as falácias sobre o interesse das mulheres nestes produtos, associando a curiosidade em produtos eróticos a falta de interesse em homens, seja por frigidez ou homossexualidade, ou até mesmo ligar o consumo deste mercado a incapacidade de se estabelecer ou gerar interesse em outros homens, ou seja, as vulgarmente chamadas de solteironas (BBC News Brasil, 2019).

Avançando um pouco mais nessa rápida passagem pela história, poderá ser citado a terceira onda do feminismo dada em meados de 1990. O auge desta nova onda e dos desdobramentos no mercado erótico se deu por meio da alta visibilidade de séries que propagavam a ideia de empoderamento feminino e aumentaram o debate sobre a normalidade e interesse da mulher em saber e praticar mais sobre sua sexualidade e, assim, buscar novas formas de se expressar sexualmente, como através de produtos eróticos. Em 1998 houve um dispositivo inovador muito comentado, este se tratava de um vibrador que, ao aparecer em uma série de televisão, causou furor dentre os telespectadores e se tornou uma febre. Tanto como produto, quanto como janela para visibilidade do mercado erótico, o vibrador famoso fez com que o mercado crescesse e 
causasse interesse em muitas pessoas para conhecer este e outros produtos eróticos (ABEME, 2019).

Sob a ótica do fortalecimento dos movimentos feministas é possível compreender algumas mudanças no setor, tanto na visão de consumo modificada pela força desta pauta social, como pelo aumento de tabu que permeia este mercado. Pois foi através dos movimentos antifeministas que as falácias sobre os consumidores deste mercado cresceram e chegaram a proporções tão elevadas que hoje ainda tem força como forma de tabu e inibem muitos a consumir ou explorar este setor. Por vezes tais características negativas são perpetuadas, gerando inibição e receio sobre o mercado e criando uma atmosfera de dúvida sobre a adesão ou não de seus produtos. Porém a cada ano certos caminhos são criados a fim de se encontrar mais liberdade utilizando, em muito, a força das pautas femininas de empoderamento e feminismo. Outra característica que se destaca neste setor é a predominância feminina, tanto nos cargos ocupados, $80 \%$, quanto ao público consumidor que chega a ultrapassar $70 \%$ no público feminino. (ABEME, 2019).

De acordo com a VEJA (2019), estudos na década de 50 demonstraram que 40\% dos entrevistados acreditavam na superioridade dos homens quando comparados as mulheres, enquanto que apenas $10 \%$ acreditam nesta afirmação nos dias de hoje. Esta modificação da visão do papel da mulher na sociedade demonstra uma das mais variadas consequências dessas pautas que vem crescendo, se fortalecendo e ganhando mais adeptos a cada ano. Direta e indiretamente o feminismo gera consequências até para os que não são ligados a pauta e toda a robustez que ganhou ao longo da história faz com que se esbarre na liberdade sexual das mulheres, levandoas a crer que não só podem como devem compreender, fortalecer e exercer a sua sexualidade da forma como queiram. Este último é enaltecido pelo fortalecimento do empoderamento feminino, visto que está atrelado a capacidade de cada mulher de se apoderar do seu lugar (seja este na sociedade, no trabalho, na sexualidade ou no âmbito que desejar) para exercer sua função de forma livre. Com isso se mostra que não só é possível, como indispensável que existam produtos para atender este público se baseando no fortalecimento da visão social e do papel exercido pela mulher (ABEME, 2019).

De 2009 a 2011, no Brasil, o mercado erótico se modificou de vez e optou por, finalmente, explorar o público feminino massivamente. Desde então o setor se manteve 
em crescimento constante, chegando a alcançar mais de $18 \%$ de crescimento, em alguns anos. Este fato também se deu pela construção de fábricas de produtos eróticos no país, que anteriormente era caracterizado por se manter a base de produtos importados, o que encarecia e inibia muitos compradores (ABEME, 2019).

Por se tratar de um assunto que, para muitos, ainda é delicado e está rodeado de tabus, além de ter um modelo relativamente novo no Brasil quanto a visão voltada para o público feminino, o setor ainda possui muitos desafios que, para alguns, soam como grandes oportunidades. As estimativas do mercado assustam quando comparadas a outros países com maior conforto e estímulo ao consumo desses produtos. Estima-se que, no Brasil, pouco mais de $85 \%$ da população nunca tenha experimentado um produto erótico, enquanto que nos EUA, por exemplo, pouco mais de $54 \%$ afirma já ter experimentado produtos eróticos em algum momento da vida (ABEME, 2019).

Como forma de exemplificar uma forma de aproveitar o crescimento e abertura de diálogo sobre sexualidade e prazer feminino dado pelas pautas levantadas neste trabalho, há a própria mídia que procura estreitar relações com um público mais desperto para estas questões, aproveitando picos nas ondas feministas, de empoderamento e nas liberdades e nuances que elas proporcionam. Como forma de trazer mais adeptos ao mercado e abrir novas possibilidades para se conquistar os consumidores, o setor acompanha de perto ondas de empoderamento quando são levantadas questões relacionadas a liberdade feminina e fenômenos que despertam o interesse do público, como filmes, séries e livros, permanecendo a postos para injetar produtos inseridos em seus contextos. Um exemplo deste fenômeno que abriu a visão do público para um nicho que ganhou força pela liberdade de dissertar sobre o assunto dentro de empoderamento foi o livro Cinquenta Tons de Cinza (2011), que instigou muitos leitores a entender e explorar práticas sobre fetichismos e BDSM, se tornando uma nova categoria a ser explorada dado o aumento do número de adeptos a estas práticas (ABEME, 2019).

Portanto, o questionamento que leva ao início da jornada deste trabalho é:

Quais são os impactos do Feminismo e Empoderamento Feminino no consumo do mercado erótico? 


\subsection{Objetivo do estudo}

Este trabalho tem como objetivo final identificar as principais características do comportamento do consumidor dentro do mercado erótico, dadas pela identificação do público com pautas sociais, no caso o Empoderamento Feminino e o Feminismo. Dentro deste objetivo inclui-se o estudo sobre o comportamento de consumo neste mercado dado pelas especificidades do nicho abordado, entendendo a visão do consumidor sobre seu senso de pertencimento ou com o seu nível de identificação e qual o impacto destes no consumo do mercado. Além destes desígnios o estudo pretende incluir, em sua concepção, esta base de pesquisa para sugerir novas estratégias de marketing para ser utilizadas neste mercado. Diante destes propósitos, os aspectos que deverão ser observados estão ligados a faixa etária, gênero, grau de afinidade com as pautas sociais abordadas, consumo no mercado erótico e estratégias de marketing.

\subsection{Objetivos intermediários do estudo}

A fim de se alcançar o objetivo final do estudo é necessário que se passe por etapas de pesquisas, observações, qualificações e análises. Portanto os objetivos intermediários devem ser esclarecidos e, assim, estão melhor especificados abaixo:

a) Analisar o perfil social dos consumidores dado pelas pautas sociais, de modo a compreender quais os perfis de consumidores estão dentro da análise do estudo.

b) Pesquisar e analisar o comportamento de consumo do nicho que deverá ser analisado neste trabalho. Esta etapa deve incluir uma análise dos aspectos do comportamento de consumo dos usuários de produtos eróticos. Com este objetivo intermediário possibilita-se identificar como os consumidores deste mercado se comportam por meio de autores, resultados de pesquisas e contato direto com consumidores do público feminino.

c) Analisar dados de comportamento de consumo no mercado, como forma de identificar os fatores que as levam a buscar e consumir estes produtos de acordo com o seu grau de identificação, ou não, com as pautas. Este objetivo visa estabelecer uma correlação dos dados de consumo com as especificidades deste público.

d) Propor estratégias de marketing de acordo com o perfil de consumo da categoria de consumidores levantada nesta pesquisa. Com este propósito entende-se que ao se conhecer mais a fundo as necessidades e especificidades dos consumidores e observar os fatores e níveis de propensão ao consumo neste mercado, pode-se estabelecer novas diretrizes quanto as estratégias de marketing dadas neste setor. 


\subsection{Delimitação e foco do estudo}

O presente estudo está delimitado a identificar os aspectos do comportamento do consumidor no mercado de produtos eróticos dado por nichos criados com base nas pautas sociais de empoderamento feminino e feminismo. O critério escolhido para classificação é baseado na história do mercado atrelada a dados da Associação Brasileira de Empresas do Mercado Erótico (ABEME), ao Instituto Brasileiro de Geografia e Estatística (IBGE) e ao Instituto de Pesquisas (DataFolha). Baseando-se nestes órgãos, os dados relacionados às mulheres feministas no Brasil, se encontra com aproximadamente $38 \%$ do público feminino. A segunda delimitação está baseada na porcentagem de consumo que este nicho, mulheres, representa atualmente dentro do mercado de produtos eróticos, alcançando expressivos $70 \%$ do consumo total nesse mercado (ABEME, 2019). Por fim, a terceira delimitação está relacionada a área geográfica a ser estudada, delimitando a análise para o segundo Estado que mais consome no Brasil, o Rio de Janeiro, atrás apenas de São Paulo (Estado de Minas, 2018). Para o seguinte trabalho são considerados os residentes destes locais, nascidos ou não na região e com análise baseada nos comportamentos de consumo deste público dentro do mercado erótico.

\subsection{Relevância do estudo}

O trabalho é relevante, pois este se trata de um tema pouco explorado pela perspectiva de análise de mercado. Este fato se dá, visto que este tema e este mercado possuem entraves quanto ao tabu e, em alguns níveis, a sua credibilidade como mercado. $O$ trabalho poderá ser benéfico ao explorar um setor que se demonstra com grande possibilidade de expansão, ao favorecer o alcance mais efetivo ao nicho aqui estudado, além de possibilitar a abertura para o estudo de novos nichos dentro deste mercado, assim, o próprio mercado poderá encontrar formas de estratégia mais específicas para que o público seja melhor explorado e mais alcançado. $O$ conhecimento dado pela base de pesquisas por nichos específicos, dados pelas pautas sociais, associado ao comportamento de consumo no mercado erótico poderá ser benéfico para as empresas pertencentes a este mercado. Estes benefícios se dão pelo fato de que esta pesquisa poderá ser utilizada pelas lojas, fábricas e demais organizações deste setor como base de análise para modificações estratégicas quanto ao marketing e até em investimentos futuros. Em suma, o presente trabalho se 
demonstra relevante tanto para acrescentar como artigo sobre um tema pouco explorado pela visão administrativa, quanto pela melhora do alcance deste mercado ao seu público, como também como base de estudo para mudanças estratégicas e de investimentos no setor por parte das empresas. 


\section{Referencial Teórico}

\subsection{O Mercado Erótico}

O surgimento do mercado erótico ocorreu em 1962, na Alemanha, com a idealizadora da primeira sexshop do mundo, a qual foi iniciada apenas como uma troca de ideias e venda produtos de porta em porta com o então criado Instituto de Higiene Conjugal, Beate Uhse, buscou criar um ambiente voltado para falar abertamente sobre métodos contraceptivos e sexualidade, mesmo que a princípio muito voltada para agradar os maridos, em uma época de maiores pudores e tabus relacionados ao assunto (Deutsche Welle, 2018). Este fato se deu, pois sua criação foi voltada para a abertura de conhecimento sobre assuntos como os mencionados acima, onde sua mãe, médica, a ensinou abertamente e a influenciou a ter esta liberdade pouco encontrada na época. Desta forma houve uma influência social familiar que a instigou de tal forma que ocasionou no início de um novo mercado. Estes conhecimentos foram utilizados para criar uma brochura contendo dicas sobre sexualidade e métodos contraceptivos, primeiramente muito associados a agradar o universo masculino dentro dos casamentos. Com o estreitamento da relação com as consumidoras, esta alemã foi ampliando o desenvolvimento de sua ideia até alcançar uma visão mais concreta de intermédio ao consumo de produtos eróticos, oferecendo-os de porta em porta. Destacase o início deste mercado na Europa, onde já havia a disseminação quanto ao conceito de Feminismo desde 1791, onde se iniciou.

No contexto histórico o Feminismo teve seu início de construção ideológica na Europa, sendo consequência dos ideais de "Liberdade, Igualdade e Fraternidade" da Revolução Francesa, criando, nas mulheres, o sentimento de desejo de mudanças sociais que as incluíssem nesses preceitos. Assim, Olympe Gouges, em 1791, criou um documento chamado "Declaração dos Direitos da Mulher e da Cidadã" como crítica ao documento "Declaração dos Direitos do Homem e do Cidadão" escrito no ano da Revolução Francesa (Toda Matéria, 2018). O mercado de produtos eróticos surgiu apenas muitos anos depois, pois anteriormente o mercado erótico era atrelado ao público masculino e dado pela prostituição. Apenas em 1962, na Alemanha, surgiu o conceito novo e em fase embrionária sobre mercado erótico e somente em 1974, nos EUA, foi finalmente criada a primeira sexshop voltada para o público feminino, após sua idealizadora, Dell Williams, ser hostilizada em uma sexshop convencional por tentar 
comprar um vibrador. A mesma, que fazia parte de movimentos feministas e tinha ideais associados ao movimento, construiu a sua empresa, a Eve's Garden, para diminuir a represália dada por possíveis consumidoras aos produtos eróticos, como para dar as mulheres maior liberdade tão predominante no movimento feminista (Boston Globe, 2015). Já a vertente do feminismo, o Empoderamento Feminino, só surgiu muitos anos depois no intuito de agregar ao movimento a ideia de empoderamento que era predominante em outros movimentos como o racial e o LGBTQIA+ (A empreendedora).

\subsection{Feminismo, Empoderamento e o comportamento do consumidor}

Segundo Kotler e Keller (2006), o comportamento de compra do consumidor é diretamente influenciado por fatores culturais, sociais, pessoais e psicológicos. Em se tratando sobre as influências sociais, os autores afirmam que estão inseridos grupos de referência como papéis sociais, status e família. Os autores ainda determinam que estes grupos de referência são dados por aqueles que exercem algum nível de influência direta ou indireta sobre as atitudes ou comportamentos de uma pessoa. Em se tratando de grupos com influência direta, também chamados de grupos de associação, estão os grupos primários, onde prevalecem relações com interação regular e informal, como família, amigos, vizinhos e colegas de trabalho. Sendo assim, estes grupos terão influência direta dada pela proximidade dos indivíduos que pertençam a eles.

Ainda sobre o grupo de referência pode-se afirmar que se trata do grupo com o qual cada pessoa se identifica e serve como ponto de comparação - ou referência para a formação específica ou geral de valores, atitudes ou comportamentos que, por fim, ocasionam em um padrão comportamental e, consequentemente, de compras. Dessa forma, fatores sociais, como os levantados pelas pautas descritas neste trabalho, influenciam no comportamento de consumidor, pois estão relacionadas a grupos que pertencem ou desejam pertencer. Outros fatores que devem ser levantados são os pessoais visto que esses abordam influências relacionadas a idade e estágio de vida, ocupação, situação econômica e estilo de vida. Este último denota que pessoas de uma mesma subcultura, classe social e ocupação podem ter estilos de vida diferentes. Como estilo de vida há dimensões centrais dadas por suas atividades, interesses e opiniões. Como opiniões entende-se as ideias sobre si mesmo, questões sociais, produtos e negócios e dá o perfil do padrão de ação e sua interação com o mundo (Princípios de Marketing, 2007). 
Para fim de esclarecimento sobre o conceito de cada questão, deve-se descrever de fato o que cada uma representa e significa. De acordo com pesquisa de 2018 feita por A Empreendedora - revista empresarial eletrônica focada especialmente no público empresarial feminino - tem-se como características do Empoderamento Feminino o ato de conceder poder de participação social às mulheres, para que estas estejam cientes sobre seus direitos e assumam o seu poder individual. Empoderamento, portanto, é uma ação dada pelo posicionamento das mulheres como um esforço de poder, para exercer - seu papel como mulher, assim, quando cada uma fortalece o seu papel, consequentemente haverá desdobramentos no papel de todas na sociedade. Em se tratando do Feminismo, o conceito se aprofunda na questão, pois se trata de um movimento ideológico, político, social e filosófico que prega a equidade social, sexual, trabalhista, política entre outros. Embora habitem o mesmo universo e sejam conceitos interligados, há diferenças entre as duas pautas que acarretam em uma adesão maior ou menor de uma ou outra de acordo com cada indivíduo. Porém vale ressaltar que Empoderamento Feminino faz parte do conceito de Feminismo, sendo consequência deste, e não o contrário, sendo o empoderamento uma ação pessoal enquanto o Feminismo é uma ação social conjunta. Esta associação se dá pelas características e pelos significados entrelaçados, porém distintos de cada uma, onde o empoderamento passa uma visão do pessoal para o social como um todo e o feminismo faz o caminho inverso.

De acordo com o Nossa Causa (Organização de sociedade civil que desenvolve projetos de impacto social, 2016) empoderamento está associado a enaltecer a si mesma, enquanto que o feminismo é uma luta pelo coletivo. Associando esta questão ao comportamento do consumidor descrito acima, pode-se por fim entender a conexão de cada pauta aos fatores comportamentais determinantes, onde o empoderamento está associado a fatores pessoais enquanto o feminismo se adequa melhor aos fatores sociais. Por terem pequenas assimilações distintas que interferem na visão do consumidor, ambos englobam o conceito sobre a mulher de forma conjunta, porém com características distintas quando vistas do ponto de vista do comportamento do consumidor (Nossa Causa, 2016).

\subsection{Pauta social como influência de consumo}

O comportamento do consumidor, ao ser influenciado pelas pautas sociais aqui descritas, segmenta o público de acordo com os dois fatores que mais pesam como 
referências nos hábitos comportamentais e de compras de cada indivíduo, sendo estas as referências pessoais e sociais (Kotler e Keller, 2006). Estes fatores levam a certeza de que ao se explorar estas referências da maneira adequada e bem estudada cada pessoa poderá ter seus princípios base enaltecidos e, assim, levando-o a compra de produtos e incentivando a demanda no mercado de produtos adultos (ABEME, 2018).

Como principal autora sobre conceitos de consumo neste mercado no Brasil, pode-se citar Luciana Walther que faz parte da composição de autores do livro lançamento do "Handbook of Research on Gender and Marketing", onde trata sobre formas de ampliar efetivamente o diálogo sobre pautas como feminismo, gênero e suas práticas quanto consumidores. A autora correlaciona pautas como a do feminismo com estratégias de marketing e práticas empresariais que intensificam a ideia de que uma pauta social, por se tratar de um fator que correlaciona referências culturais e sociais acaba por explorar diretamente dois dos principais alicerces do comportamento do consumidor. Vale reforçar que, dentro do presente trabalho há a inclusão da análise quanto ao empoderamento, sendo este caracterizado por fatores pessoais.

\subsection{Feminismo e Empoderamento no Brasil}

De acordo com pesquisa do DataFolha em 2019, analisando mulheres acima de 16 anos, $38 \%$ se consideram feministas no Brasil, enquanto 56\% rejeitam completamente uma associação a esta pauta e os demais $6 \%$ não possuem opinião formada sobre o assunto. Porém, ainda de acordo com o estudo, as mulheres mais jovens se identificam mais com a pauta, $47 \%$, enquanto mulheres de 35 a 44 anos já se associam menos, 30\%. Já em relação quanto aos benefícios do feminismo para as mulheres e para a sociedade, $45 \%$ acreditam que o feminismo traz benefícios ao público feminino, enquanto $41 \%$ indicam prejuízo as mulheres, nesta pesquisa apenas $3 \%$ se dizem indiferentes a questão e $11 \%$ preferiram não opinar. Levando em consideração os respondentes mais jovens, de 16 a 24 anos, $60 \%$ consideram o feminismo como algo positivo para as mulheres, ante $42 \%$ de 35 a 44 anos e $37 \%$ na faixa acima de 60 anos. Quanto ao resultado final dado pela avaliação quanto ao impacto do feminismo sobre a sociedade demonstrou resultados onde $47 \%$ diz que a pauta traz mais benefícios do que prejuízos ao público feminino, $40 \%$ consideram o contrário, entendendo que traz mais prejuízos, enquanto apenas $2 \%$ se diz indiferente ao assunto e $11 \%$ não responderam. Demonstrando que, por se tratar de um movimento já consolidado a mais tempo e caracterizado por um contexto mais profundo e que engloba muitas questões 
do universo feminino, o Feminismo já possui uma carga histórica tanto positiva quanto negativa a causa que interfere diretamente na percepção de cada indivíduo onde pode ser um facilitador ou limitador dependendo de quem o vê.

Por outro lado, o empoderamento teve seu início no Brasil muitos anos mais tarde e ganhou força em meados de 2010 juntamente com a disseminação das redes sociais, trazendo uma visão muito predominante no âmbito profissional e sexual como forma de encorajar mulheres a exercer sua liberdade e se apoderar do seu papel dentro de cada questão. Como forma de demonstrar a força, o crescimento da proporção da pauta de empoderamento e encorajar o movimento, a ONU Mulheres (Entidade das Nações Unidas para a Igualdade de Gênero e Empoderamento das Mulheres), criou uma lista com os 7 princípios básicos do empoderamento feminino no âmbito social e, principalmente, profissional. (Nossa Causa, 2018). Não foi por acaso que, em meados de 2010 no Brasil, também houvesse um aprofundamento de estudos dados pelo mercado erótico a fim de alcançar uma modificação do setor para, finalmente, explorar devidamente consumo do público feminino. 


\section{Metodologia}

A metodologia é onde será apresentado o universo a ser estudado na pesquisa, bem como suas variáveis, dados coletados e como estes serão relevantes ao estudo. É neste tópico que são mostradas as formas com que os dados serão recolhidos, podendo utilizar formulários, questionários, observações, dentre outras opções que viabilizem o estudo (Marconi e Lakatos, 2021).

\subsection{Tipo de pesquisa}

Como mencionado ao longo deste trabalho, o objetivo principal dissertados no mesmo é identificar o impacto do Feminismo e Empoderamento Feminino no consumo do Mercado Erótico.

Com o intuito de manter a qualidade do estudo, a metodologia de pesquisa acatada foi a exploratória e descritiva de caráter quantitativo. Esta escolha se deu por compreender que, o estudo exploratório tem como característica proporcionar maior proximidade com o problema encontrado e, portanto, tem a intenção de torna-lo mais claro ou construir hipóteses (GIL, 2008).

Segundo Gil (2008), uma pesquisa descritiva tem como propósito compreender as variáveis de um determinado grupo populacional e estabelecer as relações que essas variáveis possam ter entre si. Sendo assim, este projeto busca utilizar o método escolhido para destacar como variáveis mais importantes: associação ou não de mulheres as pautas aqui levantadas, variáveis importantes quanto a sua fase de vida como idade, estado civil dentre outros - nível de interesse, conhecimento e propensão a compra de produtos eróticos.

\subsection{Coleta de dados}

O questionário base da pesquisa utilizada foi elaborado através da plataforma Qualtrics e teve como principal abordagem o impacto de pautas femininas como empoderamento e Feminismo no consumo de produto. Tal questionário é constituído por 31 perguntas, divididas em 3 seções, conteúdo 
apresentado no Anexo I.

O objetivo de segmentar o questionário em três seções distintas foi delimitar a pesquisa principalmente para mulheres que se associam as pautas e consumissem ou tivessem interesse em consumir produtos eróticos.

$\mathrm{Na} 1^{1}$ seção continham perguntas referentes a relevância e associação das mulheres ao empoderamento e Feminismo, seu entendimento quanto a liberdade sexual que possuem, seu interesse em produtos eróticos, o quanto cada questão Empoderamento e Feminismo - seria relevante para a sua propensão ao consumo de produtos eróticos além de entender quais fatores - culturais, sociais ou pessoais - seriam mais relevantes quanto as pautas e os produtos. $\mathrm{Na} 2^{\underline{a}}$ seção as perguntas tinham o intuito de entender o comportamento de consumo ou de interesse em consumo, quais os fatores limitantes quanto ao consumo, o quanto seu entendimento quanto ao empoderamento e suas liberdades refletem no consumo e quais grupos são mais influentes para as consumidoras de produtos eróticos. $\mathrm{Na} 3^{\text {a }}$ e última seção, foram alocadas perguntas quanto ao perfil sociodemográfico das participantes da pesquisa, onde se encontram questões quanto a idade, estado civil, zona onde mora no Rio de Janeiro, nível de escolaridade e vínculo empregatício (como forma de analisar visão quanto ao valor expedido à estes produtos).

Como mencionado anteriormente, o intuito deste trabalho é realizar uma pesquisa na qual se possa compreender o impacto do Empoderamento Feminino e Feminismo no consumo de produtos eróticos e como o mercado pode usufruir do estudo como base analítica para embasar a correlação de pautas sociais com o consumo no mercado e procurar entender e estreitar relações com seus consumidores em potencial através das mesmas. Vale salientar que todas as perguntas foram elaboradas com base na literatura apresentada no capítulo 2 deste trabalho como forma de analisar através do referencial proposto.

\subsubsection{Limitações do método}

Um questionário, assim como muitos métodos de pesquisa, de acordo com Marconi \& Lakatos (2003) apresenta certas limitações. O método de pesquisa limita quem poderá responder ao questionário excluindo, a princípio, pessoas não 
alfabetizadas. Além destas, também foram excluídas pessoas do sexo masculino, mulheres não interessadas em produtos eróticos e não residentes no Rio de Janeiro.

Porém, mesmo com algumas limitações o método se mostrou eficaz por conseguir visualizar com maior precisão o comportamento de consumidoras de produtos eróticos na cidade do Rio de Janeiro. Outro benefício deste método de pesquisa é o fato de o questionário ser respondido de forma anônima, assim as respondentes tem um maior conforto e segurança, principalmente por se tratar de um mercado rodeado de tabus e, consequentemente, de limitações quanto as possibilidades de captação de respostas caso não fosse anônimo. Favoráveis a esta questão, há a garantia de proporcionar a confidenciabilidade tão necessária para que aumente a adesão de respondentes ao questionário. 


\section{Apresentação e análise de resultados}

\subsection{Descrição dos resultados}

As primeiras respostas a serem analisadas têm como objetivo entender a relação entre o nível de associação às pautas e a propensão de consumo de produtos eróticos e, de certa forma, compreender motivos que levam as mulheres a consumir, o quanto julgam que as causas sejam relevantes para esse consumo e o quanto a percepção sobre liberdade sexual serve de conexão entre a pauta e o mercado.

A fim de entender primeiramente a relevância e associação ao Feminismo e Empoderamento para as entrevistadas, foram feitas algumas perguntas. Os resultados seguem nas tabelas abaixo.

\section{Gráfico 1: Relevância de Feminismo e Empoderamento}

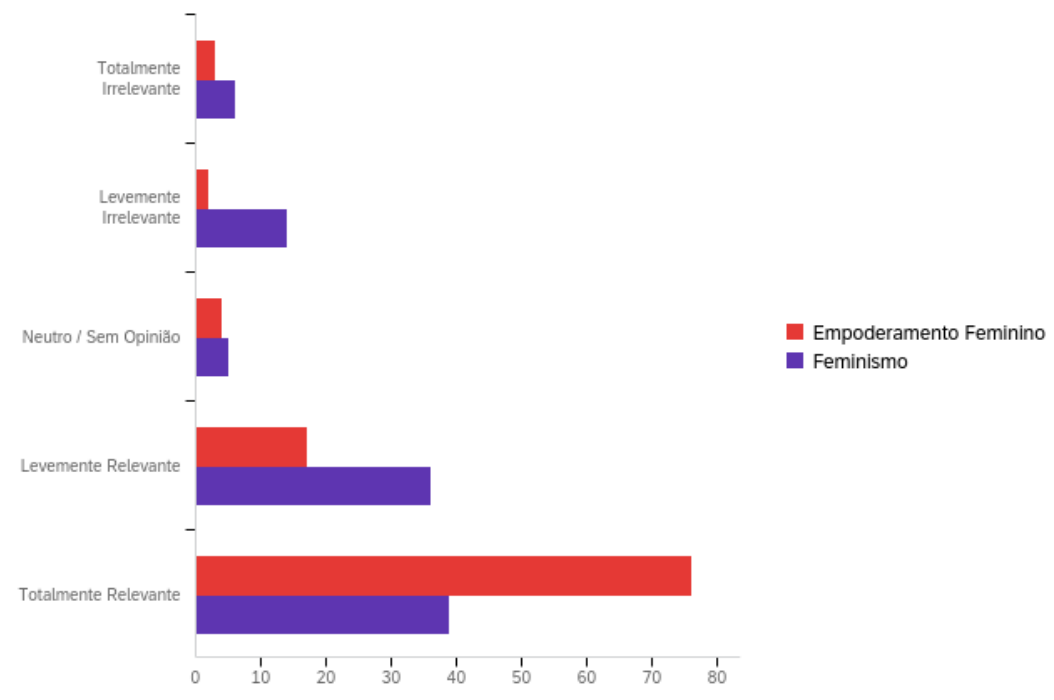

Fonte: Qualtrics, 2021

Tabela 1: Dados sobre relevância de Feminismo e Empoderamento

\begin{tabular}{|c|c|c|c|c|c|c|}
\hline Campo & $\begin{array}{l}\text { Totalmente } \\
\text { Irrelevante }\end{array}$ & $\begin{array}{l}\text { Levemente } \\
\text { Irrelevante }\end{array}$ & $\begin{array}{l}\text { Neutro / Sem } \\
\text { Opinião }\end{array}$ & $\begin{array}{l}\text { Levemente } \\
\text { Relevante }\end{array}$ & $\begin{array}{l}\text { Totalmente } \\
\text { Relevante }\end{array}$ & Total \\
\hline Empoderamento Feminino & $2,94 \% \quad 3$ & $1,96 \% \quad 2$ & $3,92 \% \quad 4$ & $\begin{array}{lll}16,67 \% & 17\end{array}$ & $74,51 \% \quad 76$ & 102 \\
\hline Feminismo & $6,00 \% 6$ & $14,00 \% \quad 14$ & $5,00 \% \quad 5$ & $36,00 \% \quad 36$ & $39,00 \% \quad 39$ & 100 \\
\hline
\end{tabular}

Fonte: Qualtrics, 2021. 


\section{Gráfico 2: Associação ao Feminismo e Empoderamento}

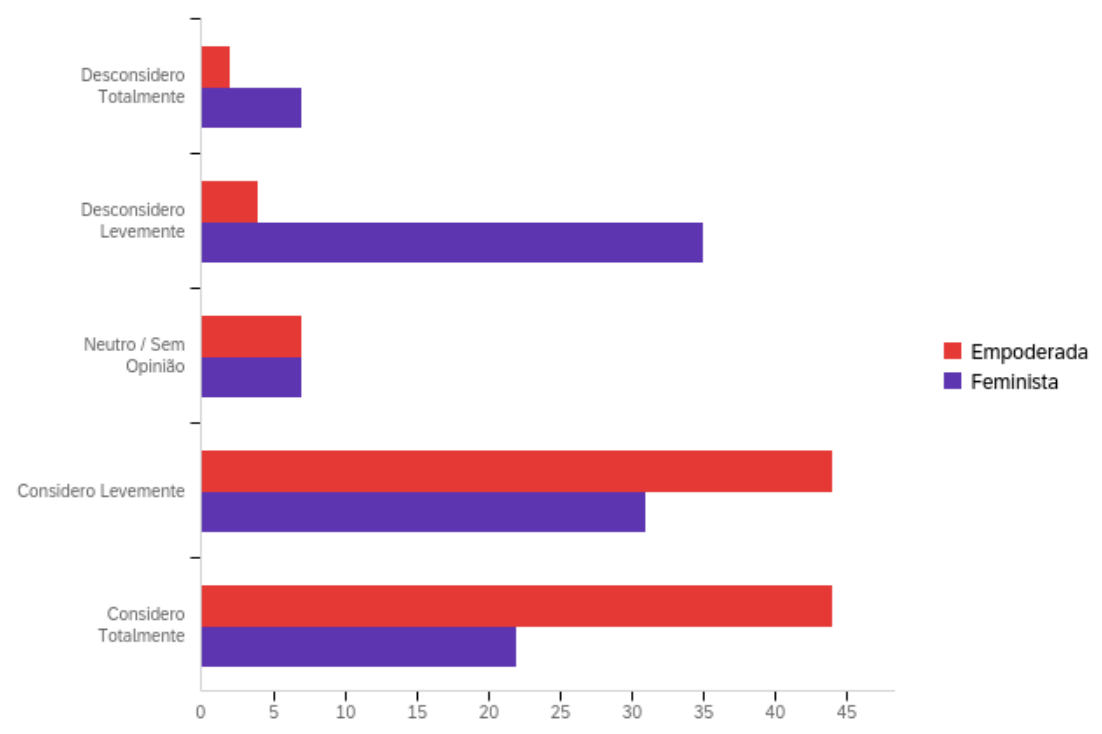

Fonte: Qualtrics, 2021.

Tabela 2: Associação ao Feminismo e Empoderamento

\begin{tabular}{|c|c|c|c|c|c|c|}
\hline Campo & Desconsidero Totalmente & Desconsidero Levemente & Neutro / Sem Opinião & Considero Levemente & Considero Totalmente & Total \\
\hline Empoderada & $1,98 \% \quad 2$ & $3,96 \% \quad 4$ & $6,93 \% 7$ & $43,56 \% \quad 44$ & $43,56 \% \quad 44$ & 101 \\
\hline Feminista & $6,86 \% \quad 7$ & $34,31 \% \quad 35$ & $6,86 \% \quad 7$ & $30,39 \% \quad 31$ & $21,57 \% \quad 22$ & 102 \\
\hline
\end{tabular}

Fonte: Qualtrics, 2021.

As tabelas e gráficos 1 e 2 acima mostram que, com relação ao Feminismo, 36\% das mulheres o enxergam como algo levemente relevante e $39 \%$ como totalmente relevante, porém quando perguntadas quanto a escala do quanto se consideram Feministas, as respostas obtidas foram, 30,39\% e 21,57\%, respectivamente. Já com relação aos dados sobre Empoderamento, houve um aumento no comparativo, onde as entrevistadas julgam que este último seja $16,67 \%$ levemente relevante e $74,51 \%$ totalmente relevante, já com relação ao quanto se consideram dentro desta pauta, os resultados foram de $46,56 \%$ tanto para levemente quanto para totalmente associadas a pauta. 
Gráfico 3: Interesse por produtos eróticos

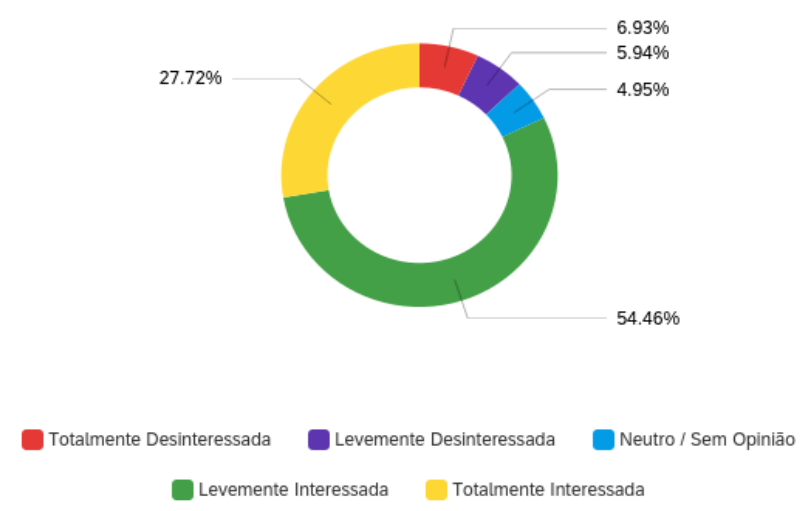

Fonte: Qualtrics, 2021.

Tabela 3: Interesse por produtos eróticos

$\begin{array}{llll}1 & \text { Totalmente Desinteressada } & 6,93 \% & 7 \\ 2 & \text { Levemente Desinteressada } & 5,94 \% & 6 \\ 3 & \text { Neutro / Sem Opinião } & 4,95 \% & 5 \\ 4 & \text { Levemente Interessada } & 54,46 \% & 55 \\ 5 & \text { Totalmente Interessada } & 27,72 \% & 28 \\ & & 101\end{array}$

Fonte: Qualtrics, 2021.

Gráfico 4: Nível de propensão a compra de produtos eróticos

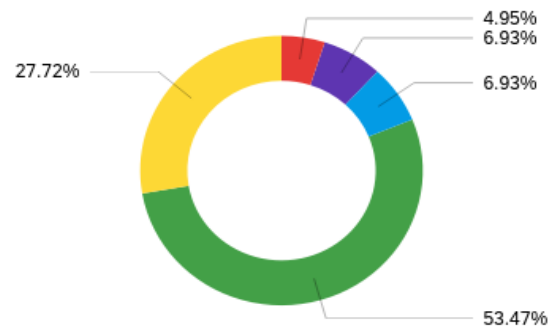

Totalmente Desinteressada Levemente Desinteressada Neutro / Sem Opiniāo

Levemente Interessada Totalmente Interessada

Fonte: Qualtrics, 2021. 
Tabela 4: Nível de propensão a compra de produtos eróticos

$\begin{array}{llrl}1 & \text { Totalmente Desinteressada } & 4,95 \% & 5 \\ 2 & \text { Levemente Desinteressada } & 6,93 \% & 7 \\ 3 & \text { Neutro / Sem Opinião } & 6,93 \% & 7 \\ 4 & \text { Levemente Interessada } & 53,47 \% & 54 \\ \quad \text { Totalmente Interessada } & 27,72 \% & 28 \\ & & & 101\end{array}$

Fonte: Qualtrics, 2021.

Os gráficos e tabelas 3 e 4 acima tem como objetivo compreender o comportamento de compra desse público com relação aos produtos eróticos e o interesse nos mesmos. Neles foi possível analisar que, dentre as entrevistadas, $54,46 \%$ são levemente interessadas e $27,72 \%$ totalmente interessadas, totalizando $82,18 \%$ positivamente interessadas em produtos eróticos. Já quanto a propensão a compra, 53,47\% constam como levemente inclinadas a compra, enquanto $27,72 \%$ se mantem como totalmente interessadas na compra destes produtos, totalizando $81,19 \%$ das entrevistadas com interesse na compra de produtos desse mercado.

\section{Gráfico 5: Influência destas pautas no consumo de produtos eróticos}

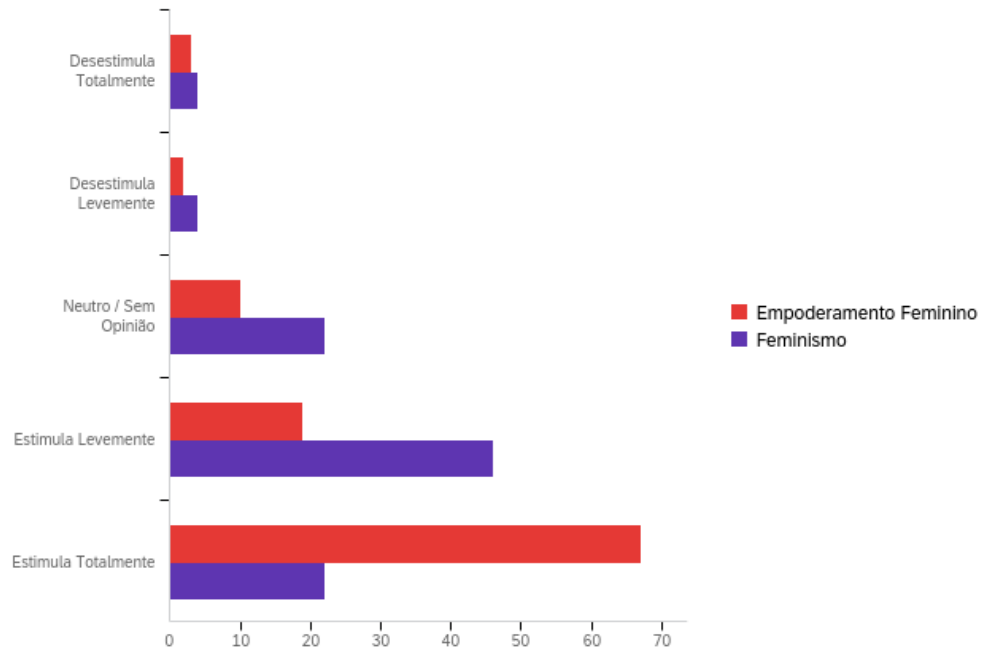

Fonte: Qualtrics, 2021. 
Tabela 5: Influência destas pautas no consumo de produtos eróticos

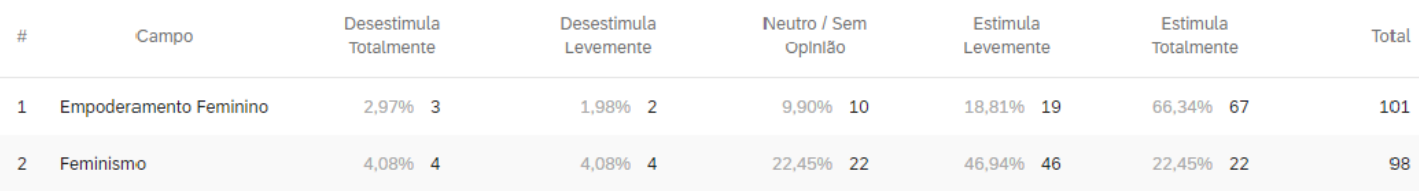

Fonte: Qualtrics, 2021.

$\mathrm{Na}$ tabela e gráfico 5 acima o objetivo principal foi entender quanto ao entendimento das entrevistadas sobre a influência que estas pautas tem no consumo de produtos eróticos. A pesquisa apontou que, com relação ao Feminismo, 46,94\% das entrevistadas acreditam que a pauta estimula levemente 0 consumo, enquanto $22,94 \%$ acreditam que a pauta estimula totalmente ao consumo nesse mercado. Quanto ao empoderamento, $18,81 \%$ acreditam que a pauta estimula levemente o consumo, enquanto $66,34 \%$ acreditam que estimula totalmente.

\section{Gráfico 6: Quantas experimentaram}

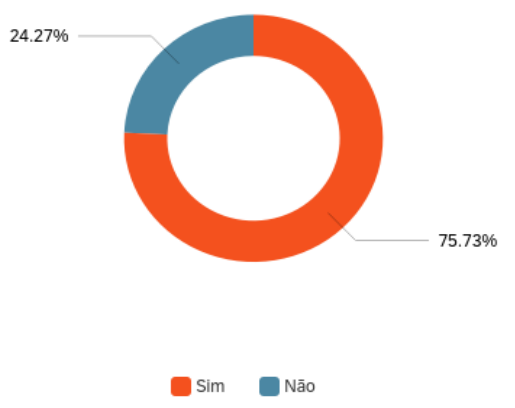

Fonte: Qualtrics, 2021.

\section{Gráfico 7: Propensão a utilizar novamente}

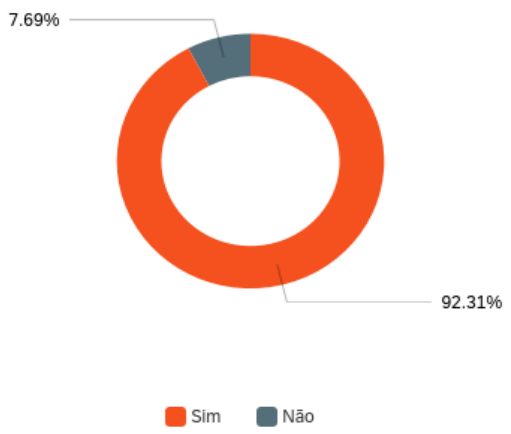

Fonte: Qualtrics, 2021 


\section{Gráfico 8: Interesse em experimentar}

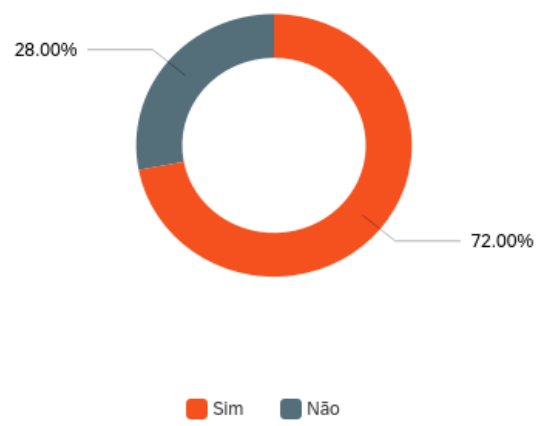

Fonte: Qualtrics, 2021.

No gráfico 6 há a indicação de quantas das entrevistadas já utilizaram produtos deste mercado, onde $75,73 \%$ indicam já ter utilizado e, como indicado no gráfico 7, 92,31\% alegam ter interesse em reutilizar produtos deste mercado. Como forma de compreender sobre as mulheres que não experimentaram, o gráfico 8 buscou analisar o interesse em experimentar, onde $72 \%$ se dizem interessadas em experimentar algum produto do mercado adulto/erótico.

\section{Gráfico 9: Consumidoras de produtos eróticos}

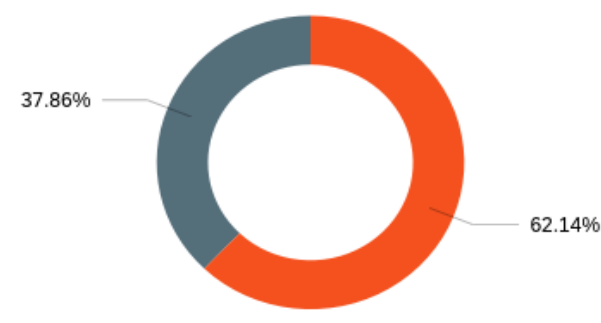

$$
\text { Sim Nāo }
$$

Fonte: Qualtrics, 2021. 


\section{Gráfico 10: Consumidoras inclinadas a comprar novamente}

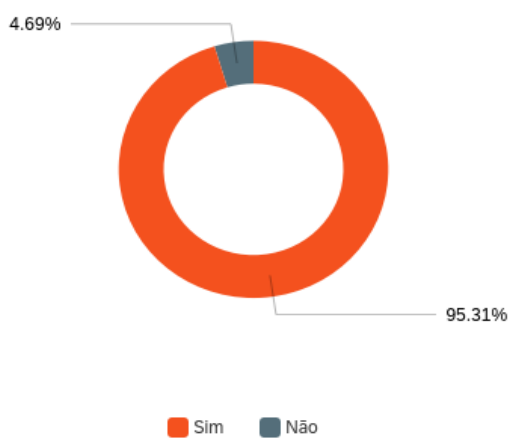

Fonte: Qualtrics, 2021.

Gráfico 11: Interessadas em comprar pela primeira vez

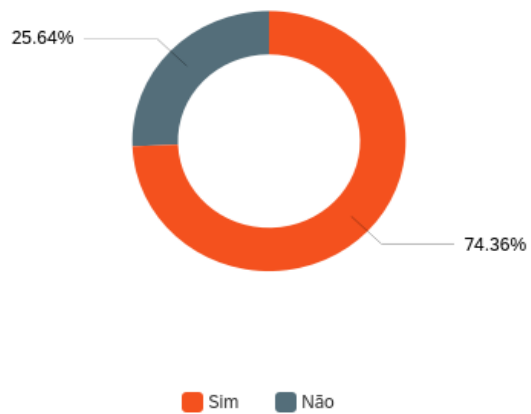

Fonte: Qualtrics, 2021.

Com relação ao núcleo de mulheres que já compraram estes produtos, no gráfico 9 pode-se encontrar que, dentre as entrevistadas, 62,14\% alegam já tem comprado e, como indicado no gráfico 10, 95,31\% estão inclinadas a comprar novamente, demonstrando uma grande taxa de satisfação no consumo deste mercado e inclinação a recompra. Com o intuito de analisar respondentes que nunca compraram produtos eróticos, o gráfico 11 mostra que, ao serem perguntadas quanto a possível inclinação a comprar pela primeira vez, $74,36 \%$ das respondentes alegam que, embora nunca tenham comprado, há interesse em comprar produtos eróticos. 
Gráfico 12: Há fatores que inibem a compra?

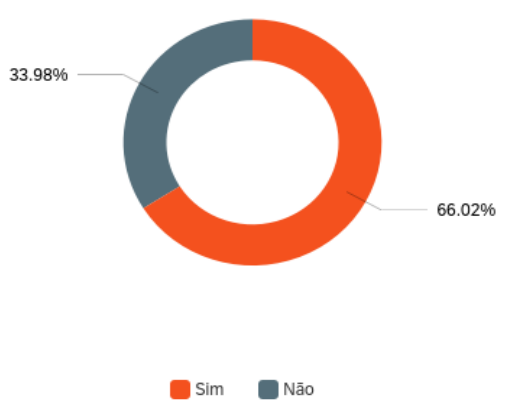

Fonte: Qualtrics, 2021.

Tabela 6: Possíveis fatores que inibem compra

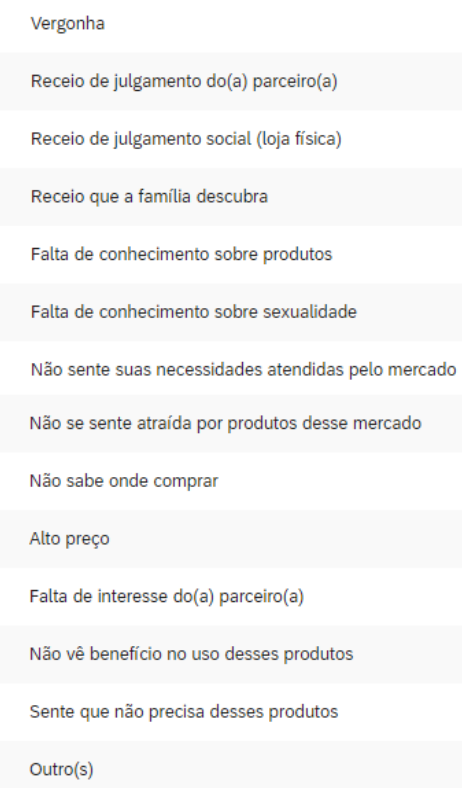

Fonte: Qualtrics, 2021.

A fim de compreender fatores que possam coibir a atitude de compra, o gráfico 12 busca analisar se há algum fator que afete esse processo, onde fatores como receio quanto a família, vergonha, julgamento social e alto preço demonstram ser os maiores inibidores, sendo três destes fatores interligados a fatores sociais e, portanto, demonstrando o peso de sua influência dentro deste mercado. 
Tabela 7: Contribuição de empoderamento, feminismo e produtos eróticos na liberdade sexual

\begin{tabular}{|c|c|c|c|c|c|c|c|c|c|}
\hline \# & Campo & $\begin{array}{l}\text { Totalmente Sem } \\
\text { Contribuição }\end{array}$ & $\begin{array}{l}\text { Levemente Sem } \\
\text { Contribuição }\end{array}$ & $\begin{array}{l}\text { Neutro / Sem } \\
\text { Opinião }\end{array}$ & $\begin{array}{c}\text { Contribui } \\
\text { Levemente }\end{array}$ & & $\begin{array}{c}\text { Contribui } \\
\text { Totalmente }\end{array}$ & & Total \\
\hline 1 & Empoderamento Feminino & $5,94 \% \quad 6$ & $3,96 \% \quad 4$ & $2,97 \% \quad 3$ & $9,90 \% \quad 1$ & 10 & $77,23 \% \quad 7$ & 78 & 101 \\
\hline 2 & Feminismo & $3,96 \% \quad 4$ & $4,95 \% \quad 5$ & $9,90 \% \quad 10$ & $36,63 \% \quad 3$ & 37 & $44,55 \% \quad 4$ & 45 & 101 \\
\hline 3 & Produtos Eróticos & $8,91 \% \quad 9$ & $10,89 \% \quad 11$ & $8,91 \% \quad 9$ & $37,62 \% \quad 3$ & 38 & $33,66 \% \quad 3$ & 34 & 101 \\
\hline
\end{tabular}

Fonte: Qualtrics, 2021.

Tabela 8: Motivos que levam a compra

\begin{tabular}{|c|c|c|}
\hline 1 & Curiosidade & $15,55 \%$ \\
\hline 2 & Para se conhecer melhor (explorar sua sexualidade e prazer) & $15,85 \%$ \\
\hline 3 & Para usufruir da sua liberdade sexual & $12,50 \%$ \\
\hline 4 & Para usar sozinha & $15,24 \%$ \\
\hline 5 & Para usar acompanhada & $12,80 \%$ \\
\hline 6 & Para apimentar a relação esporadicamente & $6,40 \%$ \\
\hline 7 & Para usar frequentemente & $4,57 \%$ \\
\hline 8 & Para datas especiais & $7,32 \%$ \\
\hline 9 & Para dar de presente & $8,84 \%$ \\
\hline & Outro(s) & $0,91 \%$ \\
\hline
\end{tabular}

Fonte: Qualtrics, 2021.

Quando perguntadas quanto aos motivos que as levam a comprar estes produtos é interessante analisar na tabela 8 quanto ao motivo "para usufruir da sua liberdade sexual", onde houve 41 respondentes associadas a esta questão, que pode ser associada a tabela 6 , onde ao serem questionadas sobre o quanto julgam que cada questão (empoderamento, feminismo e produtos eróticos) contribui para a sua liberdade sexual, $37,62 \%$ enxergam que contribui levemente e $33,66 \%$ entendem como fator que contribui totalmente. 
Tabela 9: Fontes de informação sobre produtos

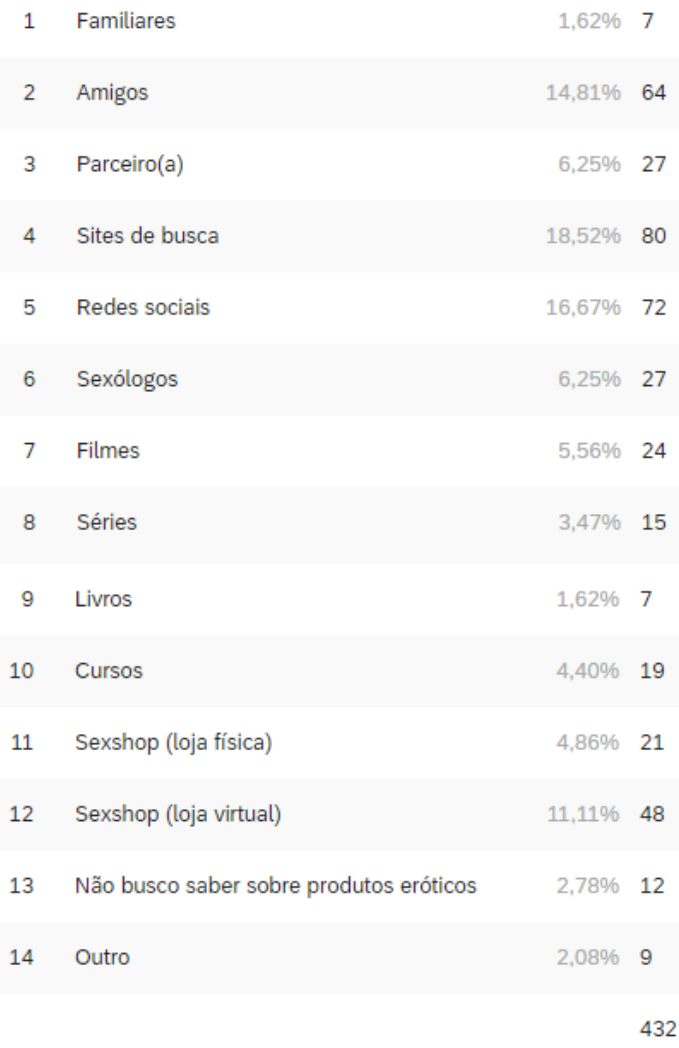

Fonte: Qualtrics, 2021.

Tendo como objetivo a análise quanto às fontes que mulheres utilizam para obter informações sobre produtos eróticos, a tabela 9 busca trazer respostas para entender esta questão, onde se destacam sites de busca, redes sociais, amigos e lojas virtuais. Sendo estas opções diretamente ligadas a fatores sociais e pessoais quanto ao estilo de vida.

Tabela 10: Pautas predominantes no ambiente social

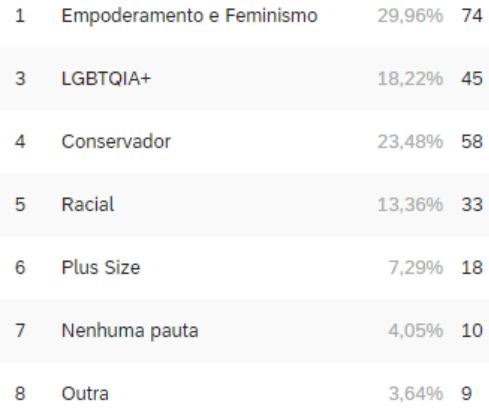

Fonte: Qualtrics, 2021 
A tabela 10 tem como objetivo analisar sobre a predominância de pautas no ambiente social das entrevistadas a fim de compreender a influência do meio no qual se está inserida. Como resultados destacaram-se a predominância de empoderamento e feminismo, seguidos de conservadores e LGBTQIA+. Tal dado pode ajudar a compreender quanto ao nível que cada pauta pode influenciar dado o comparativo com tabelas anteriores quanto ou interesse, compra e atitude de compra, demonstrando o quanto cada fator, seja social ou pessoal, pode interferir no consumo de produtos eróticos.

\section{Gráfico 13: Sexualmente ativa ou não como limitação de uso}

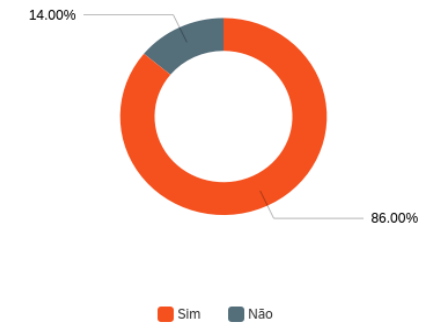

Fonte: Qualtrics, 2021.

A fim de analisar sobre a correlação entre sexualidade e consumo de produtos eróticos, a tabela 10 busca entender se, dentre as respondentes, a questão sobre ser sexualmente ativa ou não interfere no interesse e na atitude de compra como fator pessoal de estilo de vida, demonstrando que $86 \%$ são sexualmente ativas e, este fator poderá contar como limitação ao uso, embora o mercado não se limite exclusivamente a produtos que atrapalhem a condição de não sexualmente ativas.

\section{Gráfico 14: Valor destinado a produtos eróticos:}

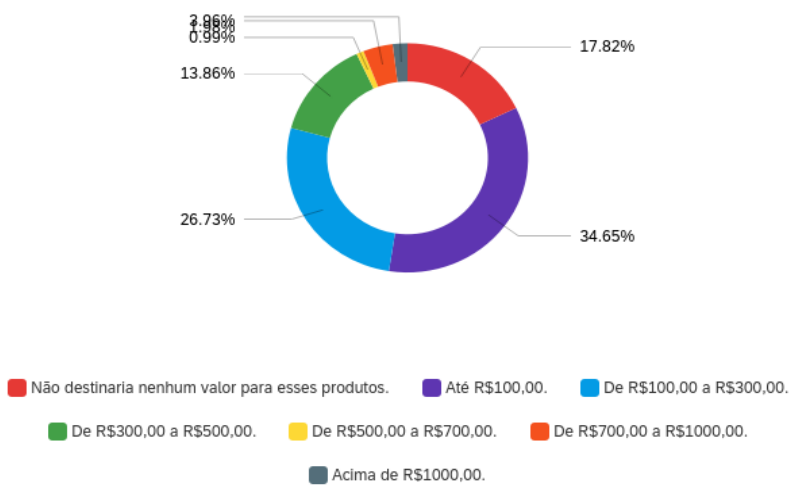

Fonte: Qualtrics, 2021. 
Por fim, para compreender sobre a atitude de compra e o quanto estariam dispostas a demandar para tais produtos dentro de um período de 1 ano, o gráfico 14 demonstra que independente de ter interesse em produtos ou não, 17,82\% das entrevistadas não estão dispostas a demandar nenhuma margem de renda para estes produtos, enquanto $34,65 \%$ destinariam até $R \$ 100,00,26,73 \%$ de $R \$ 100,00$ a $R \$ 300,00,13,86 \%$ de $R \$ 300,00$ a $R \$ 500,00,0,99 \%$ de $R \$ 500,00$ a $R \$ 700,00$, $3,96 \%$ de $R \$ 700,00$ a $R \$ 1000,00$ e 1,98\% afirma que destinaria acima de $\mathrm{R} \$ 1000,00$. Totalizando $82,18 \%$ das entrevistadas afirmando que destinariam alguma renda para fins de consumo no mercado erótico.

\subsection{Descrição da amostra}

Através do questionário aplicado por intermédio da plataforma Qualtrics, conseguiu-se um total de 101 respondentes, com o objetivo de coletar dados para uma pesquisa quantitativa, onde não foram aceitas respostas do público masculino, repetidas ou de residentes fora do Estado do Rio de Janeiro.

Com a intenção de compreender melhor as 101 entrevistadas, foram feitos alguns cruzamentos de resultados com a consolidação de dados para que fossem analisados e para que fosse possível criar tabelas e gráficos que fossem capazes de exprimir e caracterizar o estudo de forma mais clara.

Tabela 11: Idade

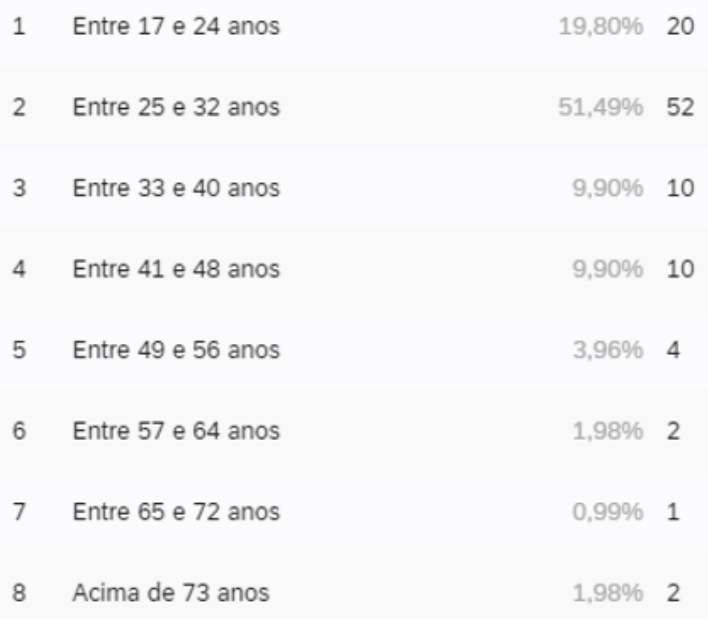

Idade. Fonte: Qualtrics, 2021. 
Baseado nos dados obtidos através da pesquisa, foi possível constatar que houve uma predominância de respondentes entre 25 e 32 anos, totalizando $51,49 \%$ da amostra. Também foi possível observar que a menor faixa etária encontrada foi de 65 a 72 anos (0,99\%), seguida de 57 a 64 e acima de 73 anos com 1,98\% cada, como pôde ser observado na tabela 11.

Tabela 12: Estado civil e relacionamento

\begin{tabular}{|c|c|c|}
\hline 1 & Solteira sem parceiros(as) sexuais & $25,74 \%$ \\
\hline 2 & Solteira sem parceiros(as) sexuais fixos & $15,84 \%$ \\
\hline 3 & Com parceiro(a) sexual fixo ou Namorando(a) & $35,64 \%$ \\
\hline 4 & União estável & $5,94 \%$ \\
\hline 5 & Casada & $10,89 \%$ \\
\hline 6 & Separada & $0,00 \%$ \\
\hline 7 & Divorciada & $0,00 \%$ \\
\hline 8 & Viúva & $2,97 \%$ \\
\hline 9 & Outro & $2,97 \%$ \\
\hline
\end{tabular}

Fonte: Qualtrics, 2021.

$\mathrm{Na}$ tabela 12 acima foi possível exprimir dados sobre o status de relacionamento ou estado civil de forma a entender o perfil da amostra. Destaca-se mulheres com parceiros fixos ou namorando com $35,64 \%$ das respondentes e a ausência de mulheres separadas ou divorciadas. 
Tabela 13: Grau de escolaridade

\begin{tabular}{|c|c|c|}
\hline 1 & Primeiro Grau Completo & $1,98 \%$ \\
\hline 2 & Primeiro Grau Incompleto & $0,00 \%$ \\
\hline 3 & Ensino Médio Completo & $7,92 \%$ \\
\hline 4 & Ensino Médio Incompleto & $5,94 \%$ \\
\hline 5 & Graduação Completo & $34,65 \%$ \\
\hline 6 & Graduação Incompleto & $19,80 \%$ \\
\hline 7 & Pós Graduação & $23,76 \%$ \\
\hline 8 & Mestrado & $3,96 \%$ \\
\hline & Doutorado & $1,98 \%$ \\
\hline
\end{tabular}

Fonte: Qualtrics, 2021.

Com relação ao grau de escolaridade, é possível destacar, na tabela 13, respondentes com a graduação completa (34,65\%), e com menor aparição na amostra há a ausência de mulheres com primeiro grau incompleto e pouca aparição com primeiro grau completo e doutorado, ambos com 1,98\%.

Tabela 14: Tipo de instituição de ensino

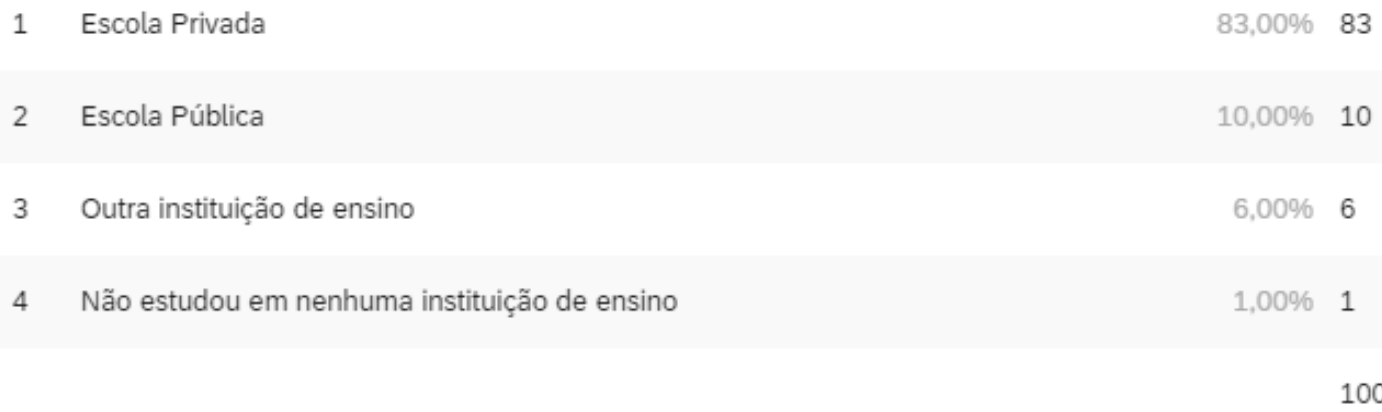

Fonte: Qualtrics, 2021.

Na tabela 14 destacada acima é possível analisar o perfil de mulheres quanto ao tipo de instituição de ensino, onde foi possível exprimir dados indicando uma predominância de estudantes de escolas privadas, com $83 \%$ da amostra, 
enquanto apenas 1\% não estudou em nenhuma instituição de ensino convencional.

Tabela 15: Ocupação

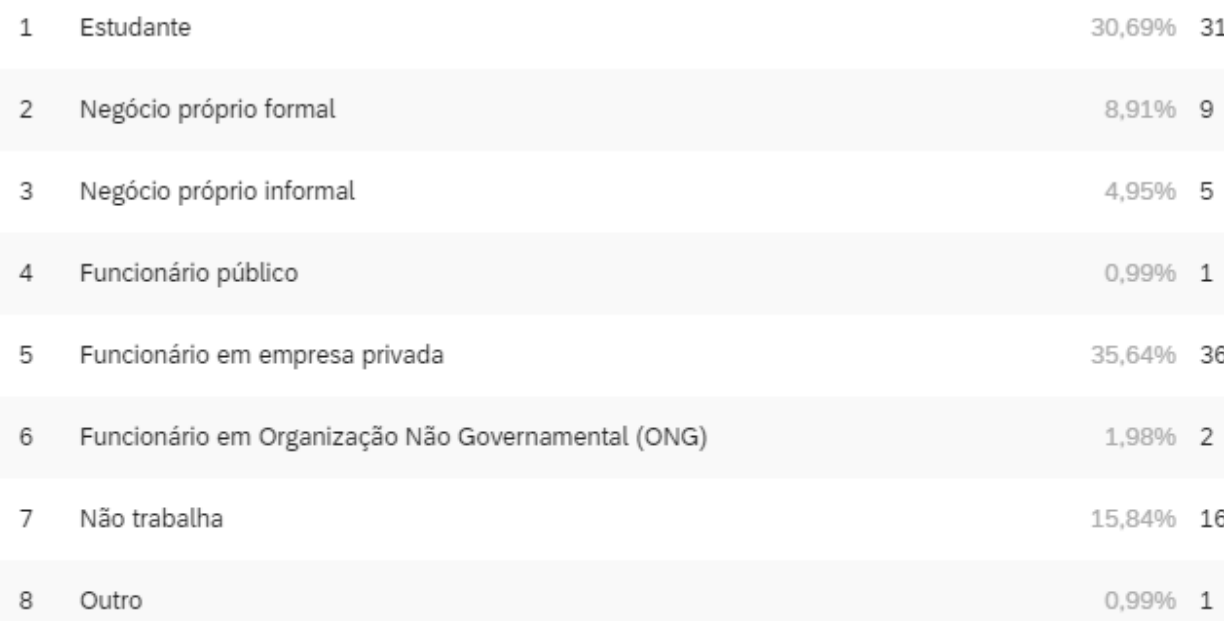

Fonte: Qualtrics, 2021.

Um dado importante a ser considerado com relação ao perfil de mulheres da amostra é a ocupação dada pela tabela 15, visto que estabelece uma correlação a obtenção de renda para destinar ou não parte da mesma a obtenção de produtos eróticos, também havendo correlação com a limitação vide preço. Há portanto, em destaque, funcionárias de empresas privadas, 35,64\% das respondentes, seguida por $30,69 \%$ de estudantes.

Tabela 16: Região do Rio de Janeiro

1 Zona Oeste

2 Zona Sul

3 Zona Norte

4 Zona Central
$65,35 \% 66$

$24,75 \% \quad 25$

$5,94 \% 6$

$3,96 \% \quad 4$

Fonte: Qualtrics, 2021.

Por fim, é possível analisar na tabela 16 a zona do estado do Rio de Janeiro onde residem as mulheres da amostra e entender a disposição das 
mesmas, onde destacam-se as residentes da zona oeste como grande parcela da amostra, 65,35\%, enquanto que a menor parcela reside na zona central do Rio de Janeiro, sendo estas $3,96 \%$ da amostra.

\subsection{Análise dos resultados}

Através da descrição dos resultados abordados no item 4.1, pode-se iniciar a análise compreendendo primeiramente a percepção da amostra quanto a relevância e a associação às pautas estudadas, entendendo que, embora exista uma inclinação positiva quanto ao entendimento da relevância, dada pela tabela 1 e gráfico 1, onde há uma associação das mulheres ao feminismo de $36 \%$ levemente relevante e $39 \%$ totalmente relevante, para $30,39 \%$ e $21,57 \%$, respectivamente no nível de associação à pauta. Enquanto que no Empoderamento há um expressivo aumento quanto a visão da relevância, demonstrando que $16,67 \%$ julgam como levemente relevante e $74,51 \%$ totalmente relevante, porém há uma associação de $46,56 \%$ tanto para levemente quanto para totalmente, compreendendo que embora uma pauta esteja inserida na outra, a percepção das mulheres é consideravelmente diferente e sua atitude com relação a pauta é consideravelmente diferente.

Na tabela e gráfico 5 se destaca a importância no entendimento das mulheres quanto a correlação de produtos e pautas. Nesta tabela foi possível compreender que no público feminino há uma tendência a enxergar o empoderamento como fator totalmente estimulante no consumo de produtos, alcançando $66,34 \%$, enquanto $18,81 \%$ como levemente estimulante, sendo assim $85,15 \%$ da amostra possui uma associação positiva do empoderamento como estimulo ao consumo de produtos eróticos. Enquanto que o Feminismo alcança $69,39 \%$ com inclinação positiva a esta associação, onde $22,45 \%$ é visto como totalmente estimulante e $46,94 \%$ levemente estimulante. Tais dados indicam que, embora existam percepções diferentes quanto as pautas, há uma significativa visão como estimulante ao consumo por parte das mulheres, entendendo que tais movimentos podem ser caminhos para a uma atitude de compra positiva dada, principalmente, pelo fator pessoal de estilo de vida predominantes na pauta de empoderamento.

$\mathrm{Na}$ tabela 8, quando perguntadas quanto aos meios que utilizam para obter informações sobre produtos, a amostra demonstra que há uma 
predominância quanto aos fatores pessoais de estilo de vida incluindo respostas de maior adesão como sites de busca e redes sociais entendendo que estes fazem parte de medidas de dimensões centrais do consumidor, como atividades, interesses e opiniões (Princípios de Marketing, 2007), enquanto que, a terceira maior influência é dada por amigos, inferindo a importância dos fatores sociais no comportamento de consumo da amostra.

É indispensável compreender e analisar a fundo dados dos gráficos 9,10 e 11, visto que demonstram o interesse dado por mulheres que já compraram ou nunca compraram e associar ao gráfico 12 e tabela 6, onde se encontram respostas relacionadas aos possíveis fatores limitantes, fazendo com que se consiga esclarecê-los e o mercado tenha base para buscar estratégias que os combatam. Nesta tabela é exposto que, dentre estes fatores, tanto o de receio familiar, quanto o de julgamento social, estão ligados diretamente ao fator social, enaltecendo sua importância no comportamento de consumo do mercado. Vale destacar que vergonha pode ser enquadrado como fator social ou, em algumas exceções como fator pessoal e o alto valor como percepção dada por fatores psicológicos (Princípios de Marketing, 2007).

Quando se analisa a tabela 9, quanto aos meios de informação sobre produtos, pode-se encontrar dados que demonstram que, sites de busca e redes sociais lideram como fontes, sendo estes pertencentes a estilo de vida dado por fatores pessoais, porém há a importância dada por fatores sociais com relação aos amigos, embora exista uma expressiva diminuição de outros membros pertencentes a fatores sociais, como parceiros(as) e, principalmente, familiares.

Tendo em vista o propósito de se compreender sobre o ambiente no qual a amostra está inserida e as características dadas por possíveis pautas com as quais tenha maior proximidade no seu meio social, os resultados demonstram que há uma expressiva presença das pautas de empoderamento e feminismo, seguidas de conservadores e LGBTQIA+, sendo estes fatores sociais e, em certa instância, pessoais e, portanto, limitadores ou estimuladores do comportamento do consumidor. Estes dados devem ser analisados correlacionando com o nível de relevância e afinidade dados pelas tabelas 1 e 2 e gráficos 1 e 2, pois demonstram que a relevância não é necessariamente fator de estímulo para que se associem as pautas, porém há uma correlação entre uma expressiva associação ao empoderamento e a presença desta pauta no ambiente social da amostra. 


\section{Conclusões}

O estudo buscou analisar o impacto de pautas como Empoderamento Feminino e Feminismo no comportamento do consumidor de produtos eróticos, compreendendo a percepção quanto a relevância e associação as pautas, ambiente social do qual mulheres fazem parte, nível de interesse no mercado de produtos eróticos, propensão a compra e fatores limitantes a ela, com o propósito de responder:

- Há relação entre as pautas de empoderamento e feminismo e consumo de produtos eróticos?

Com a finalidade de obter respostas para tal pesquisa, foram analisadas 101 mulheres a partir de 17 anos, residentes do Rio de Janeiro, que tinham níveis de associação às pautas de empoderamento e feminismo e níveis de interesse em produtos eróticos.

Em conseguinte foram analisados dados onde foi possível obter correlações quanto ao nível de relevância e associação as pautas, nível de interesse no mercado dado por compradoras e mulheres que nunca compraram associado as limitações ao consumo e correlacionar com fatores que influenciam o comportamento de consumo, além de compreender a faixa etária, grau de escolaridade, ocupação e estado civil ou status de relacionamento dado pelas respondentes.

Dentro destas premissas foi possível compreender quais fatores do comportamento do consumidor mais influenciam a amostra e quais limitam o comportamento de consumo de produtos eróticos. Como destaque há amigos como membros influentes mais presentes dos fatores sociais, além do papel social associado as pautas de empoderamento e feminismo, porém há limitações quanto aos familiares, enquanto os fatores pessoais se demonstram importantes quanto ao estilo de vida como influência ao consumo, porém há limitações relacionadas ao alto preço, podendo ser exploradas no âmbito da percepção em fatores psicológicos.

Houve uma predominância de respondentes de 17 a 32, onde há correlações com o seu status de relacionamento e estado civil, além de 
ocupação e grau de escolaridade.

Dentro da faixa etária em destaque também há uma correlação com o nível de associação e percepção quanto a relevância das pautas onde há uma não correlação direta entre empoderamento e feminismo. Mesmo que o primeiro esteja inserido no contexto do segundo, a amostra expõe uma tendência a aderir o empoderamento feminino, parte do movimento feminista - partindo da premissa de que empoderamento é uma parte do feminismo - porém há ressalvas quanto a questões que distinguem uma pauta da outra, fazendo com que sejam percebidas como pautas, em parte, distintas.

Como forma de aplicar o estudo na prática há a proposição de estratégias que favoreçam a adesão de consumidoras, principalmente a fim de explorar o interesse mencionado tanto por recompra, quanto para novas consumidoras. Deve-se considerar primeiramente o destaque quanto ao perfil dado por faixa etária, de 17 a 24 e 25 a 32 alcançando $71,29 \%$ da amostra e correlacionar com a taxa de adesão às pautas sendo $87,12 \%$ (leve e totalmente) associadas ao empoderamento e $51,96 \%$ (leve e totalmente) associadas ao feminismo. Ainda fazendo menção a estes dados, há a necessidade de associar a percepção quanto a influência de empoderamento no consumo de produtos eróticos alcançando $85,15 \%$ (leve e totalmente influente) enquanto o feminismo alcança $69,39 \%$ de influência no consumo destes produtos. Vale ressaltar a taxa de adesão aos produtos, onde o empoderamento alcança $87,12 \%$ (leve e totalmente) da amostra, enquanto o feminismo alcança 51,96\% (leve e totalmente). A partir destes dados pode-se inferir a predominância de associadas principalmente ao empoderamento, nas faixas etárias destacadas e a compreensão de como entendem quanto a influência deste como influência ao consumo. Portanto, o mercado poderá explorar estratégias que visem estreitar relações com as consumidoras a partir, principalmente, da pauta de empoderamento dada a afinidade, associação e predominância de mulheres nesta faixa etária com interesse em produtos eróticos e na pauta.

Outra questão a ser analisada na tomada de decisão quanto a estratégia escolhida pelo mercado é a correlação do interesse de compra e recompra com a presença de fatores que inibem o consumo. $O$ interesse nos produtos, se destaca alcançando $82,18 \%$ (leve e totalmente interessadas) enquanto a propensão a compra alcança $81,19 \%$ (leve e totalmente), entendendo que a expressiva parcela interessada em produtos está propensa a consumir neste 
mercado. Dentre elas, há o interesse em experimentar alcançando $72 \%$, ainda uma margem expressiva inclinada a não só conhecer sobre estes produtos, porém a experimentá-los, passando de processo de busca de informações para uma propensão a atitude de compra. Ao mercado é proposto que explore essa característica de propensão a compra adotando estratégias a fim de inibir comportamentos dissonantes, tendo em vista o grau de envolvimento exigido na compra de produtos eróticos.

Já quanto a parcela da amostra que já consumiu (62,14\%), 95,31\% demonstra propensão a recompra, favorecendo a taxa de satisfação após a quebra da barreira pré compra, a partir destes dados. Portanto, é possível propor ao mercado estratégias baseadas em comportamento pós compra, podendo diminuir a dissonância cognitiva e se beneficiando da expressiva parcela de clientes satisfeitos e, portanto, propensos a consumir novamente, além de ter um custo menor quando comparado com o de captar novos clientes. Porém vale destacar o índice de mulheres interessadas em comprar pela primeira vez, onde $74,36 \%$ demonstram propensão a primeira compra, a estes indivíduos deverá ser oferecido um maior investimento que desempenhe de forma clara fatores que favoreçam e influenciem no reconhecimento da necessidade e estímulo a busca por informações, entendendo que haverá uma avaliação de alternativas e, consequentemente, o mercado deverá favorecer estes processos de forma a convencer as interessadas na escolha da marca que alcance a melhor estratégia que incluam e explorem estas questões.

Além das questões anteriores, para fim de captar mulheres interessadas em experimentar e comprar produtos eróticos, devem ser considerados os fatores que as inibem a compra. O estudo destaca que, na amostra, 66,02\% alega ter fatores que inibem a compra, dentro dos possíveis causadores de inibição há como fator principal o receio quanto a descoberta da família sobre o uso $(16,55 \%)$, seguido de vergonha $(14,53 \%)$, ambos relacionados a fatores sociais de influência no comportamento do consumidor, além do fator preço $(14,53 \%)$ como fator psicológico e, julgamento social $(13,51 \%)$ novamente um fator social. Com estes dados compreende-se pautas sociais influenciam mulheres com fatores sociais e que, para elas, estes fatores esbarram em sua percepção quanto a liberdade sexual (tabela 7) e alcançam o mercado erótico através de seus produtos, portanto há a necessidade de se estabelecer estratégias que reconheçam os fatores sociais como grande inibidores e compreendam que tais fatores são determinantes para que mulheres 
aumentem o consumo neste mercado.

Para as demais mulheres não associadas a empoderamento e feminismo, bem como pertencentes as demais faixas etárias, de 33 para cima $(28,71 \%)$ é sugerido um novo estudo para que se entenda quais questões podem influenciar seu comportamento dentro do mercado erótico e, consequentemente, possibilitar uma propensão a compra e adesão de produtos eróticos. 


\section{Referências Bibliográficas}

ABEME: ASSOCIAÇÃO BRASILEIRA DE EMPRESAS DO MERCADO ERÓTICO. Mercado erótico. 2019. Disponível em: <www.mercadoerotico.org>. Acesso em 10 de Outubro de 2020.

A EMPREENDEDORA. A diferença entre empoderamento feminino e feminismo. 2018. Disponível em: <https://aempreendedora.com.br/adiferenca-entre-o-empoderamento-feminino-e-o-feminismo/>. Acesso em 12 de março

de 2021.

BBC NEWS BRASIL. Os mitos e verdades sobre as origens do vibrador. 2019. Disponível em: <www.bbc.com/portuguese/vert-fut46444693.amp>. Acesso em 10 de Outubro de 2020.

BOSTON GLOBE: Dell Williams, 92, fouder of sex shop catering to women. $2015 . \quad$ Disponível em: <https://www.bostonglobe.com/metro/obituaries/2015/03/14/dell-williamsfounder-sex-shop-for-women-champion-liberating-womensexuality/hkforKkGvKfykRaBSRfEqM/story.html>. Acesso em 02 de abril de 2021.

DATAFOLHA: INSTITUTO DE PESQUISAS. $\mathbf{3 8 \%}$ das mulheres brasileiras se consideram feministas. 2019. Disponível em: <https://datafolha.folha.uol.com.br/opiniaopublica/2019/04/1987743-38das-mulheres-brasileiras-se-consideram-feministas.shtml>. Acesso em 12 de Outubro de 2020. 
DEUTSCHE WELLE: Beate Uhse, a mulher por trás da primeira sexshop do mundo. 2019. Disponível em: <https://www.dw.com/ptbr/beate-uhse-a-mulher-por-tr\%C3\%A1s-da-primeira-sex-shop-domundo/a-50990337>. Acesso em 10 de Outubro de 2020.

ESTADO DE MINAS. Mulheres impulsionam mercado erótico, que crescerá mais de $30 \%$ este ano. 2018. Disponível em: <https://www.em.com.br/app/noticia/economia/2019/09/30/internas_econo $\mathrm{mia}, 1088927 /$ mulheres-impulsionam-mercado-erotico-que-crescera-maisde-30-em-2019.shtml>. Acesso em: 30 de março de 2021.

GIL, A. Métodos e Técnicas de Pesquisa Social. São Paulo: Editora Atlas, 6 Ed. São Paulo. Livros Técnicos e Científicos. 2008.

IBGE: INSTITUTO BRASILEIRO DE GEOGRAFIA E ESTATÍSTICA. Estatística de gênero: indicadores sociais de mulheres no Brasil. 2019. Disponível em: <https://educa.ibge.gov.br/jovens/materiasespeciais/materias-especiais/20453-estatisticas-de-genero-indicadoressociais-das-mulheres-no-brasil.html >. Acesso em 12 de Outubro de 2020.

KOTLER, P.; KELLER, K. L. Administração de marketing. $12^{\circ}$ Ed. Rio de Janeiro: Livros Técnicos e Científicos, 2006. 92p.

KOTLER, P.; ARMSTRONG, G. Princípios de Marketing. 12 Ed. Rio de Janeiro: Livros Técnicos e Científicos, 2007. 97p. 
LUCIANA WALTHER. Dialética dos Extremos: Refutando Mitos sobre Consumo Erótico Feminino. MARCELO DE REZENDE PINTO E GEORGIANA LUNA BATINGA (Orgs.). Cultura e Consumo no Brasil: Estado Atual e Novas Perspectivas. 1ed., Belo Horizonte: PUC Minas, 2018.

LUCIANA WALTHER. Humility of Things: Analyzing Material Culture's Salience in the Erotic Industry. Consumer Culture Theory Conference, Anaheim, EUA, 2017.

MARCONI, M; LAKATOS, E. Fundamentos da Metodologia Científica. 9 Ed. São Paulo. Livros Técnicos e Científicos. Editora Atlas, 2021.

NOSSA CAUSA. Por que o empoderamento feminino é importante? 2016. Disponível em: <https://nossacausa.com/por-que-oempoderamento-feminino-eimportante/\#: :text=O\%20empoderamento\%20feminino\%2C\%20basicam ente\%2C\%20se,papel\%20de\%20todas\%20na\%20sociedade>. Acesso em 12 de março de 2021.

PURE PEOPLE. O empoderamento é entendido como uma série de atitudes que levam a uma valorização e autorreconhecimento do "ser mulher". Ele ganha voz através de vários grupos. Disponível em: $<$ https://www.purepeople.com.br/midia/o-empoderamento-e-entendidocomo-uma-ser_m2508294>. Acesso em 11 de Maio de 2021.

SOLOMON, M. R. O comportamento do consumidor: comprando, possuindo e sendo. 5. Ed. Rio de Janeiro: Livros Técnicos e Científicos. 2002. 103p. 
TODA MATÉRIA. Feminismo. 2018. Disponível em: $<$ https://www.todamateria.com.br/feminismo/>. Acesso em 24 de abril de 2021.

UNIVERSIDADE DE CAXIAS DO SUL - UCS. Empoderamento: Significado, benefícios e surgimento. 2020. Disponível em: <https://ead.ucs.br/blog/empoderamento\#: :text=O\%20conceito\%20surgi u\%20nos\%20Estados,a\%20ascens\%C3\%A30\%20das\%20redes\%20soci ais. >. Acesso em 12 de Maio de 2021. 


\section{Anexo I}

\section{Questionário:}

Q1

Antes de mais nada gostaria de deixar claro algumas questões sobre este questionário:

- Essa pesquisa é destinada ao público feminino residente no Rio de Janeiro.

- Tem o objetivo de coletar informações para o meu Trabalho de Conclusão de Curso na Puc-Rio.

-Todas as respostas são confidenciais.

- Não tem o intuito de vender nenhum produto.

- Por favor, usem apenas sua opinião como resposta.

- Certifique-se de fechar a pesquisa apenas após a confirmação de que suas respostas foram registradas.

Desde já agradeço pelo tempo destinado a respondê-lo!

Q2 - Marque na escala abaixo, o quanto cada questão é relevante para você:

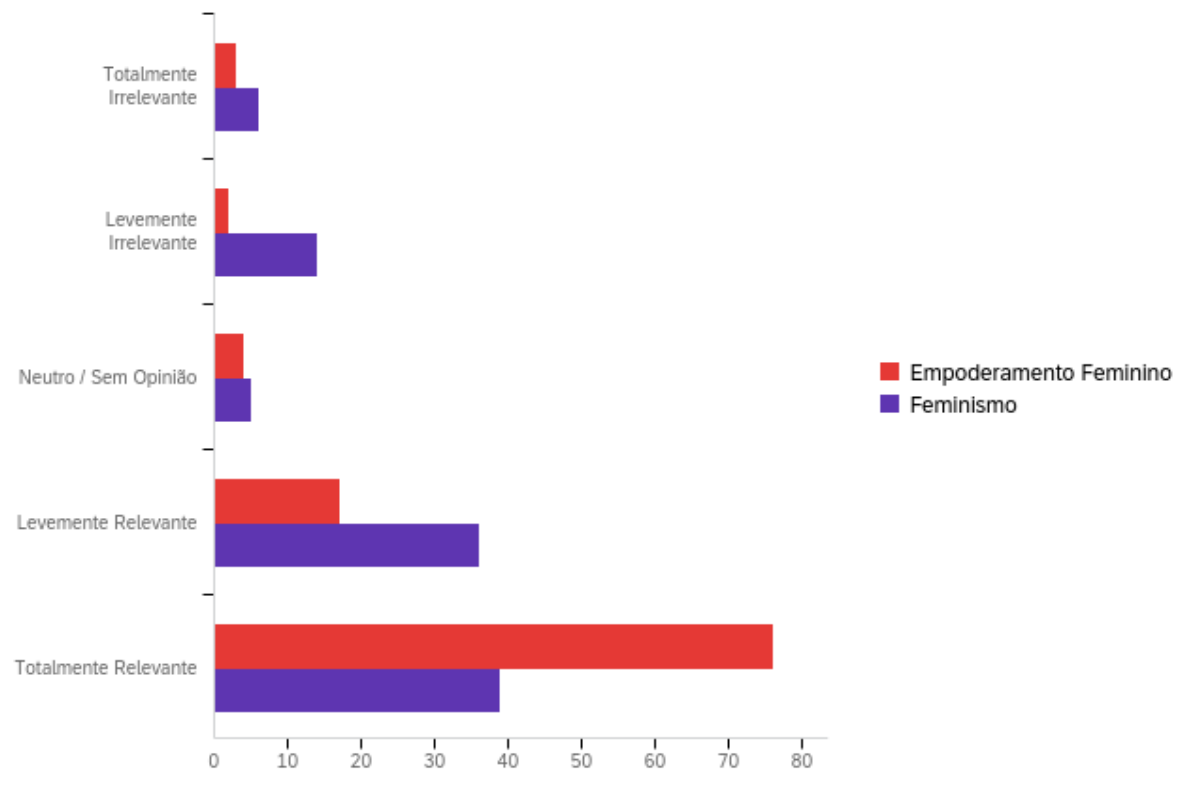

\begin{tabular}{|r|r|r|r|r|r|r|r} 
\# & Field & Mínimo & Máximo & Média & $\begin{array}{r}\text { Desvio } \\
\text { padrão }\end{array}$ & Variância & Contagem \\
\hline 1 & $\begin{array}{r}\text { Empoderamento } \\
\text { Feminino }\end{array}$ & 1.00 & 5.00 & 4.58 & 0.89 & 0.79 & 102 \\
\hline 2 & Feminismo & 1.00 & 5.00 & 3.88 & 1.24 & 1.53 & 100 \\
\hline
\end{tabular}




\begin{tabular}{|c|c|c|c|c|c|c|c|c|c|c|c|c|}
\hline \# & Pergunta & $\begin{array}{r}\text { Totalme } \\
\text { nte } \\
\text { Irrelevan } \\
\text { te }\end{array}$ & & $\begin{array}{r}\text { Leveme } \\
\text { nte } \\
\text { Irrelevan } \\
\text { te }\end{array}$ & & $\begin{array}{l}\text { Neutr } \\
0 / \\
\text { Sem } \\
\text { Opini } \\
\text { ão }\end{array}$ & & $\begin{array}{r}\text { Leveme } \\
\text { nte } \\
\text { Relevan } \\
\text { te }\end{array}$ & & $\begin{array}{r}\text { Totalme } \\
\text { nte } \\
\text { Relevan } \\
\text { te }\end{array}$ & & $\begin{array}{r}\text { Tot } \\
\text { al }\end{array}$ \\
\hline 1 & $\begin{array}{r}\text { Empoderam } \\
\text { ento } \\
\text { Feminino }\end{array}$ & $2.94 \%$ & 3 & $1.96 \%$ & 2 & $\begin{array}{r}3.92 \\
\%\end{array}$ & 4 & $16.67 \%$ & $\begin{array}{l}1 \\
7\end{array}$ & $74.51 \%$ & $\begin{array}{l}7 \\
6\end{array}$ & 102 \\
\hline 2 & Feminismo & $6.00 \%$ & 6 & $14.00 \%$ & & $\begin{array}{r}5.00 \\
\%\end{array}$ & 5 & $36.00 \%$ & $\begin{array}{l}3 \\
6\end{array}$ & $39.00 \%$ & $\begin{array}{l}3 \\
9\end{array}$ & 10 \\
\hline
\end{tabular}

Q3 - Marque na escala abaixo, o quanto você se considera:

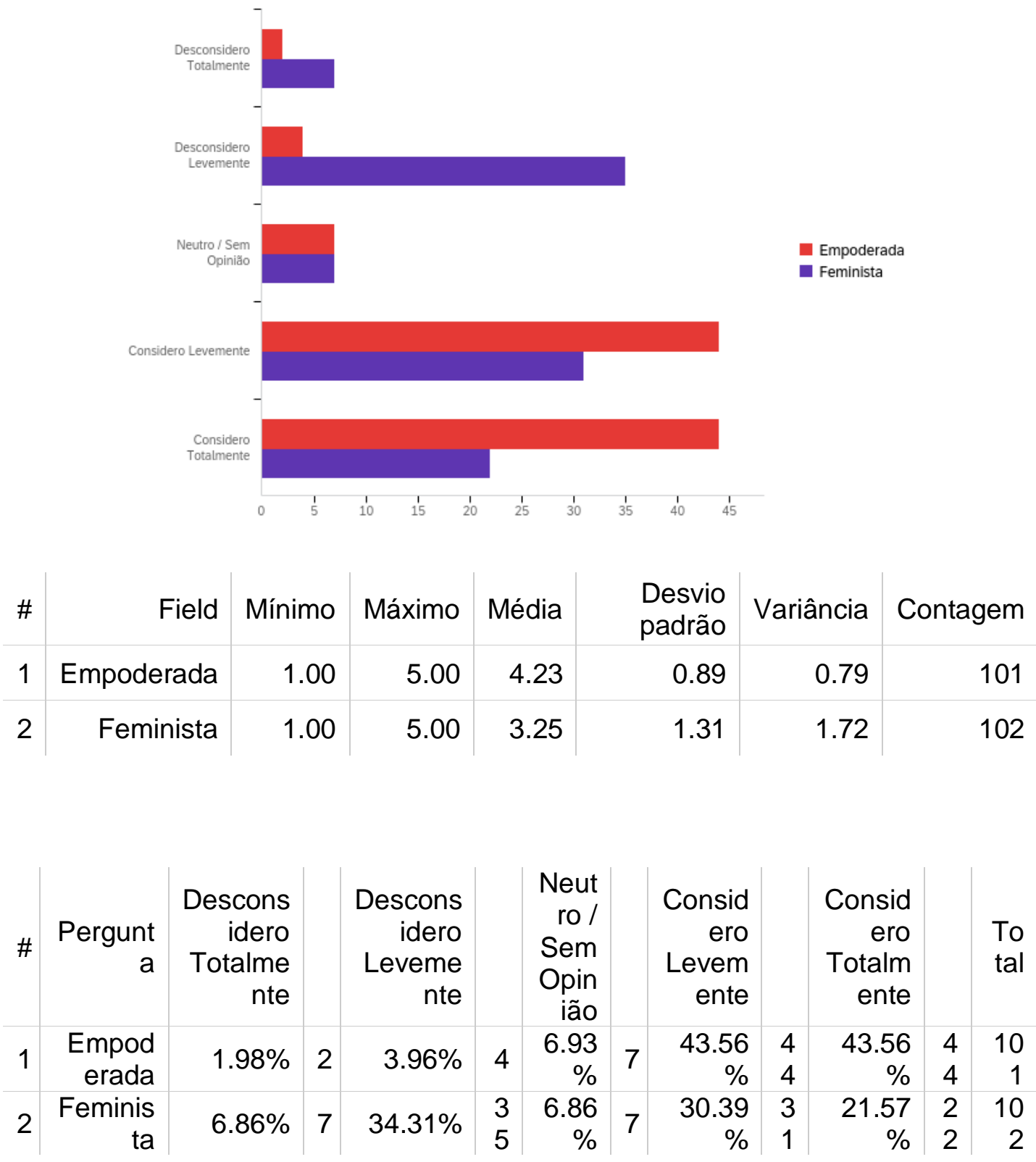

Q4 - Marque na escala abaixo, o quanto você se sente sexualmente livre: 


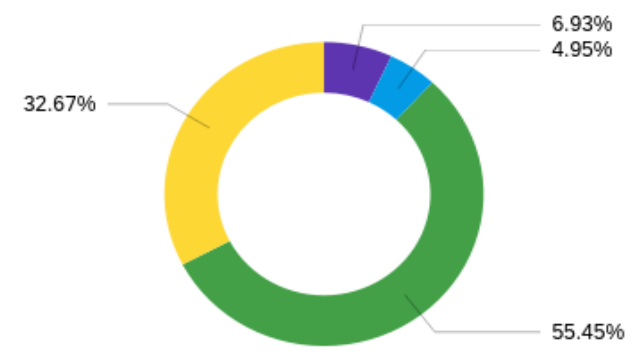

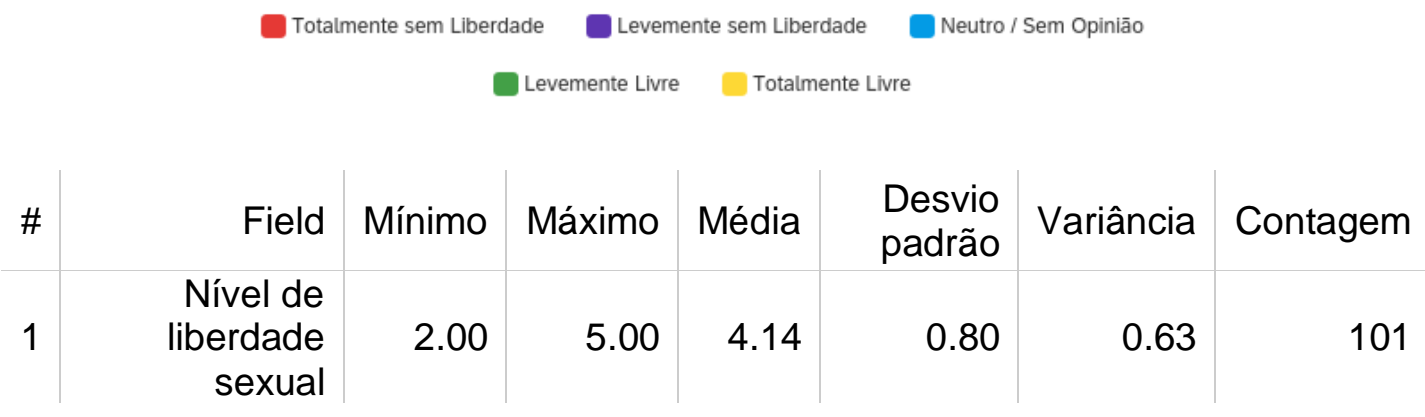

\begin{tabular}{|l|r|r|r}
$\#$ & Resposta & $\%$ & Contagem \\
\hline 1 & Totalmente sem Liberdade & $0.00 \%$ & 0 \\
\hline 2 & Levemente sem Liberdade & $6.93 \%$ & 7 \\
\hline 3 & Neutro / Sem Opinião & $4.95 \%$ & 5 \\
\hline 4 & Levemente Livre & $55.45 \%$ & 56 \\
\hline 5 & Totalmente Livre & $32.67 \%$ & 33 \\
\hline & Total & $100 \%$ & 101
\end{tabular}


Q5 - Marque na escala abaixo, o quanto você se interessa por produtos do mercado adulto/erótico (lingerie, fantasias, acessórios, cosméticos do ramo, etc):

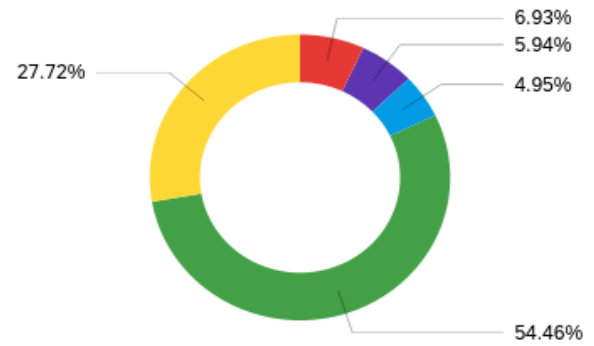

Totalmente Desinteressada

Levemente Desinteressada

Neutro / Sem Opiniāo

Levemente Interessada

Totalmente Interessada

\begin{tabular}{|l|r|r|r}
$\#$ & Resposta & $\%$ & Contagem \\
\hline 1 & Totalmente Desinteressada & $6.93 \%$ & 7 \\
\hline 2 & Levemente Desinteressada & $5.94 \%$ & 6 \\
\hline 3 & Neutro / Sem Opinião & $4.95 \%$ & 5 \\
\hline 4 & Levemente Interessada & $54.46 \%$ & 55 \\
\hline 5 & Totalmente Interessada & $27.72 \%$ & 28 \\
\hline & Total & $100 \%$ & 101 \\
\hline
\end{tabular}

Q6 - Marque na escala abaixo, o quanto você se sente inclinada a comprar um produto erótico:

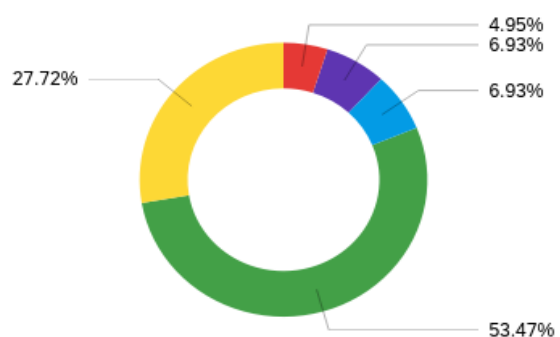

Totalmente Desinteressada

Levemente Desinteressada

Neutro / Sem Opiniāo 


\begin{tabular}{|c|c|c|c|c|c|c|c|}
\hline \# & Field & Mínimo & Máximo & Média & $\begin{array}{l}\text { Desvio } \\
\text { padrão }\end{array}$ & Variância & Contagem \\
\hline 1 & $\begin{array}{r}\text { Nível de } \\
\text { interesse de } \\
\text { compra }\end{array}$ & 1.00 & 5.00 & 3.92 & 1.03 & 1.06 & 101 \\
\hline
\end{tabular}

\begin{tabular}{|r|r|r|r}
$\#$ & Resposta & $\%$ & Contagem \\
\hline 1 & Totalmente Desinteressada & $4.95 \%$ & 5 \\
\hline 2 & Levemente Desinteressada & $6.93 \%$ & 7 \\
\hline 3 & Neutro / Sem Opinião & $6.93 \%$ & 7 \\
\hline 4 & Levemente Interessada & $53.47 \%$ & 54 \\
\hline 5 & Totalmente Interessada & $27.72 \%$ & 28 \\
\hline & Total & $100 \%$ & 101 \\
\hline
\end{tabular}

Q7 - Marque na escala abaixo, o quanto você julga que cada questão pode estimular no seu consumo de produtos eróticos.

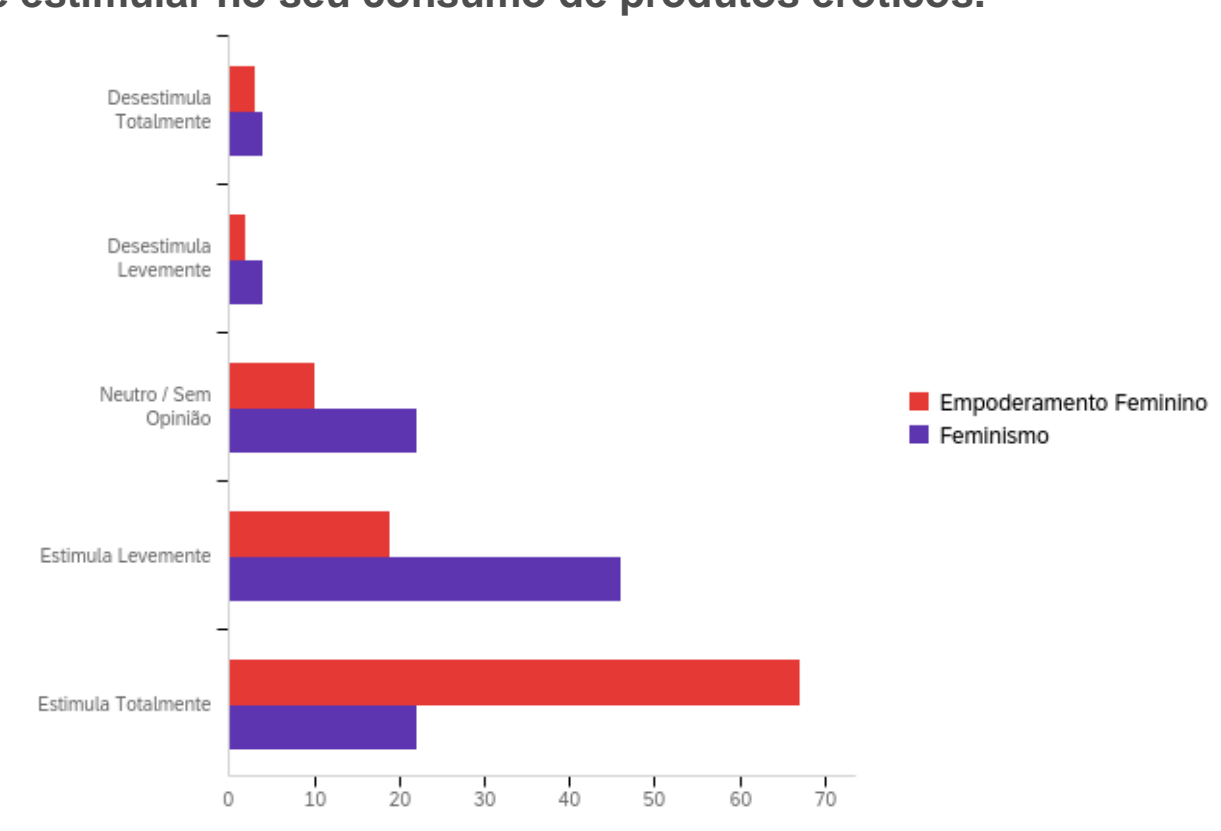

\begin{tabular}{r|r|r|r|r|r|r|r} 
\# & Field & Mínimo & Máximo & Média & $\begin{array}{r}\text { Desvio } \\
\text { padrão }\end{array}$ & Variância & Contagem \\
\hline 1 & $\begin{array}{r}\text { Empoderamento } \\
\text { Feminino }\end{array}$ & 1.00 & 5.00 & 4.44 & 0.96 & 0.92 & 101 \\
\hline 2 & Feminismo & 1.00 & 5.00 & 3.80 & 0.97 & 0.94 & 98 \\
\hline
\end{tabular}




\begin{tabular}{|c|c|c|c|c|c|c|c|c|c|c|c|c|}
\hline \# & Pergunta & $\begin{array}{r}\text { Desesti } \\
\text { mula } \\
\text { Totalm } \\
\text { ente }\end{array}$ & & $\begin{array}{r}\text { Desesti } \\
\text { mula } \\
\text { Levem } \\
\text { ente }\end{array}$ & & $\begin{array}{c}\text { Neut } \\
\text { ro / } \\
\text { Sem } \\
\text { Opin } \\
\text { ião }\end{array}$ & & $\begin{array}{r}\text { Estimu } \\
\text { la } \\
\text { Levem } \\
\text { ente }\end{array}$ & & $\begin{array}{r}\text { Estimu } \\
\text { la } \\
\text { Totalm } \\
\text { ente }\end{array}$ & & $\begin{array}{l}\text { To } \\
\text { tal }\end{array}$ \\
\hline 1 & $\begin{array}{r}\text { Empodera } \\
\text { mento } \\
\text { Feminino }\end{array}$ & $2.97 \%$ & 3 & $1.98 \%$ & 2 & $\begin{array}{r}9.90 \\
\%\end{array}$ & $\begin{array}{l}1 \\
0\end{array}$ & $\begin{array}{r}18.81 \\
\%\end{array}$ & $\begin{array}{l}1 \\
9\end{array}$ & $\begin{array}{r}66.34 \\
\%\end{array}$ & $\begin{array}{l}6 \\
7\end{array}$ & $\begin{array}{r}10 \\
1\end{array}$ \\
\hline 2 & $\begin{array}{r}\text { Feminism } \\
0\end{array}$ & $4.08 \%$ & 4 & $4.08 \%$ & 4 & $\begin{array}{r}22.4 \\
5 \%\end{array}$ & $\begin{array}{l}2 \\
2\end{array}$ & $\begin{array}{r}46.94 \\
\%\end{array}$ & $\begin{array}{l}4 \\
6\end{array}$ & $\begin{array}{r}22.45 \\
\%\end{array}$ & $\begin{array}{l}2 \\
2\end{array}$ & 98 \\
\hline
\end{tabular}

Q8 - Marque na escala abaixo, o quanto você julga que cada questão contribui para a sua liberdade sexual.

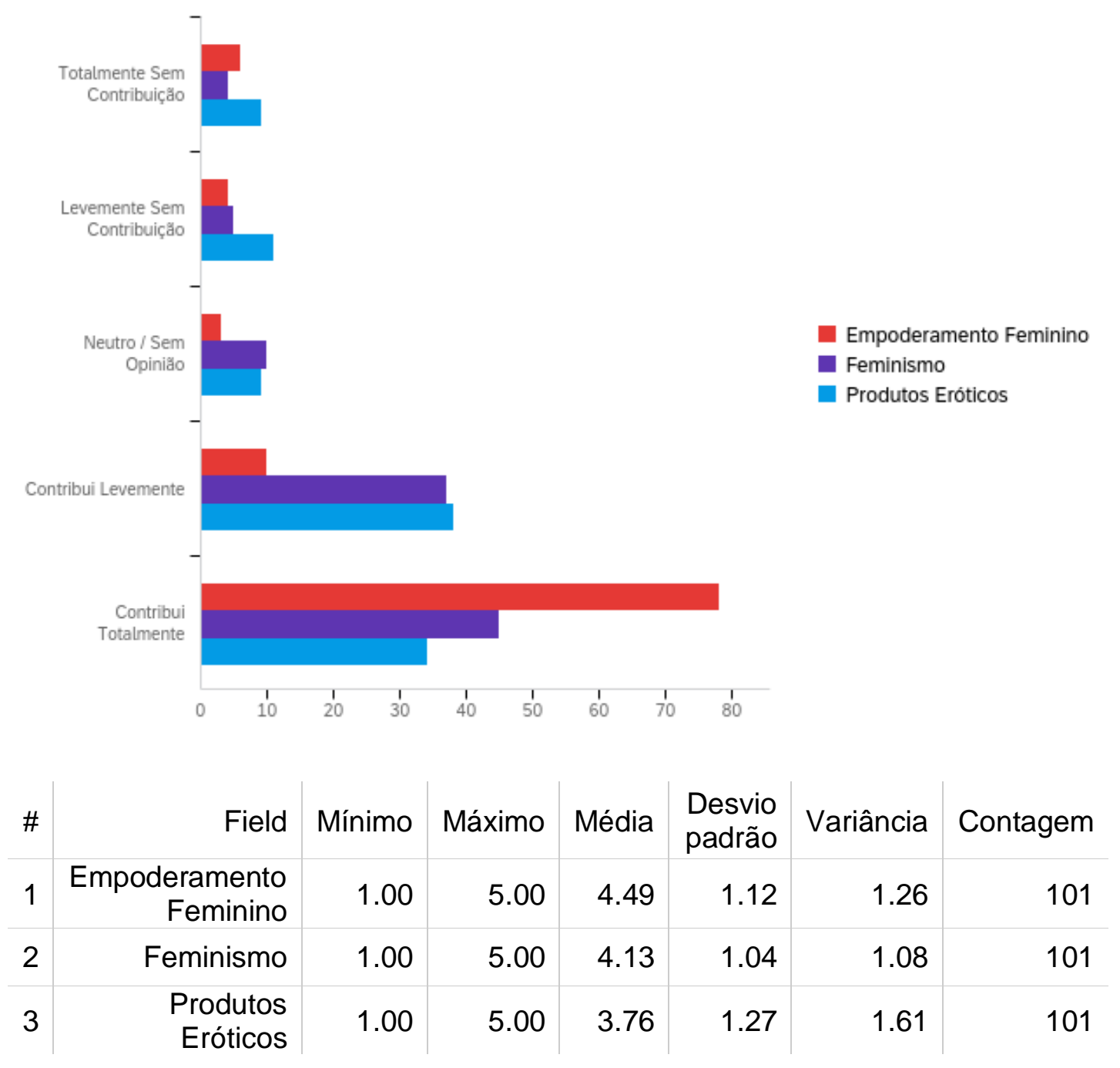




\begin{tabular}{|c|c|c|c|c|c|c|c|c|c|c|c|c|}
\hline \# & Pergunta & $\begin{array}{r}\text { Totalm } \\
\text { ente } \\
\text { Sem } \\
\text { Contrib } \\
\text { uição }\end{array}$ & & $\begin{array}{r}\text { Levem } \\
\text { ente } \\
\text { Sem } \\
\text { Contrib } \\
\text { uição }\end{array}$ & & $\begin{array}{l}\text { Neut } \\
\text { ro / } \\
\text { Sem } \\
\text { Opin } \\
\text { ião }\end{array}$ & & $\begin{array}{r}\text { Contri } \\
\text { bui } \\
\text { Levem } \\
\text { ente }\end{array}$ & & $\begin{array}{r}\text { Contri } \\
\text { bui } \\
\text { Totalm } \\
\text { ente }\end{array}$ & & $\begin{array}{l}\text { To } \\
\text { tal }\end{array}$ \\
\hline 1 & $\begin{array}{r}\text { Empoder } \\
\text { amento } \\
\text { Feminino }\end{array}$ & $5.94 \%$ & 6 & $3.96 \%$ & 4 & $\begin{array}{r}2.97 \\
\%\end{array}$ & 3 & $9.90 \%$ & $\begin{array}{l}1 \\
0\end{array}$ & $\begin{array}{r}77.23 \\
\%\end{array}$ & $\begin{array}{l}7 \\
8\end{array}$ & $\begin{array}{r}10 \\
1\end{array}$ \\
\hline 2 & $\begin{array}{r}\text { Feminism } \\
0\end{array}$ & $3.96 \%$ & 4 & $4.95 \%$ & 5 & $\begin{array}{r}9.90 \\
\%\end{array}$ & $\begin{array}{l}1 \\
0\end{array}$ & $\begin{array}{r}36.63 \\
\%\end{array}$ & $\begin{array}{l}3 \\
7\end{array}$ & $\begin{array}{r}44.55 \\
\%\end{array}$ & $\begin{array}{l}4 \\
5\end{array}$ & $\begin{array}{r}10 \\
1\end{array}$ \\
\hline 3 & $\begin{array}{r}\text { Produtos } \\
\text { Eróticos }\end{array}$ & $8.91 \%$ & 9 & $10.89 \%$ & $\begin{array}{l}1 \\
1\end{array}$ & $\begin{array}{r}8.91 \\
\%\end{array}$ & 9 & $\begin{array}{r}37.62 \\
\%\end{array}$ & $\begin{array}{l}3 \\
8\end{array}$ & $\begin{array}{r}33.66 \\
\%\end{array}$ & $\begin{array}{l}3 \\
4\end{array}$ & $\begin{array}{r}10 \\
1\end{array}$ \\
\hline
\end{tabular}

Q9 - Marque na escala abaixo, o quanto você se sente confortável em falar sobre empoderamento e/ou feminismo com:

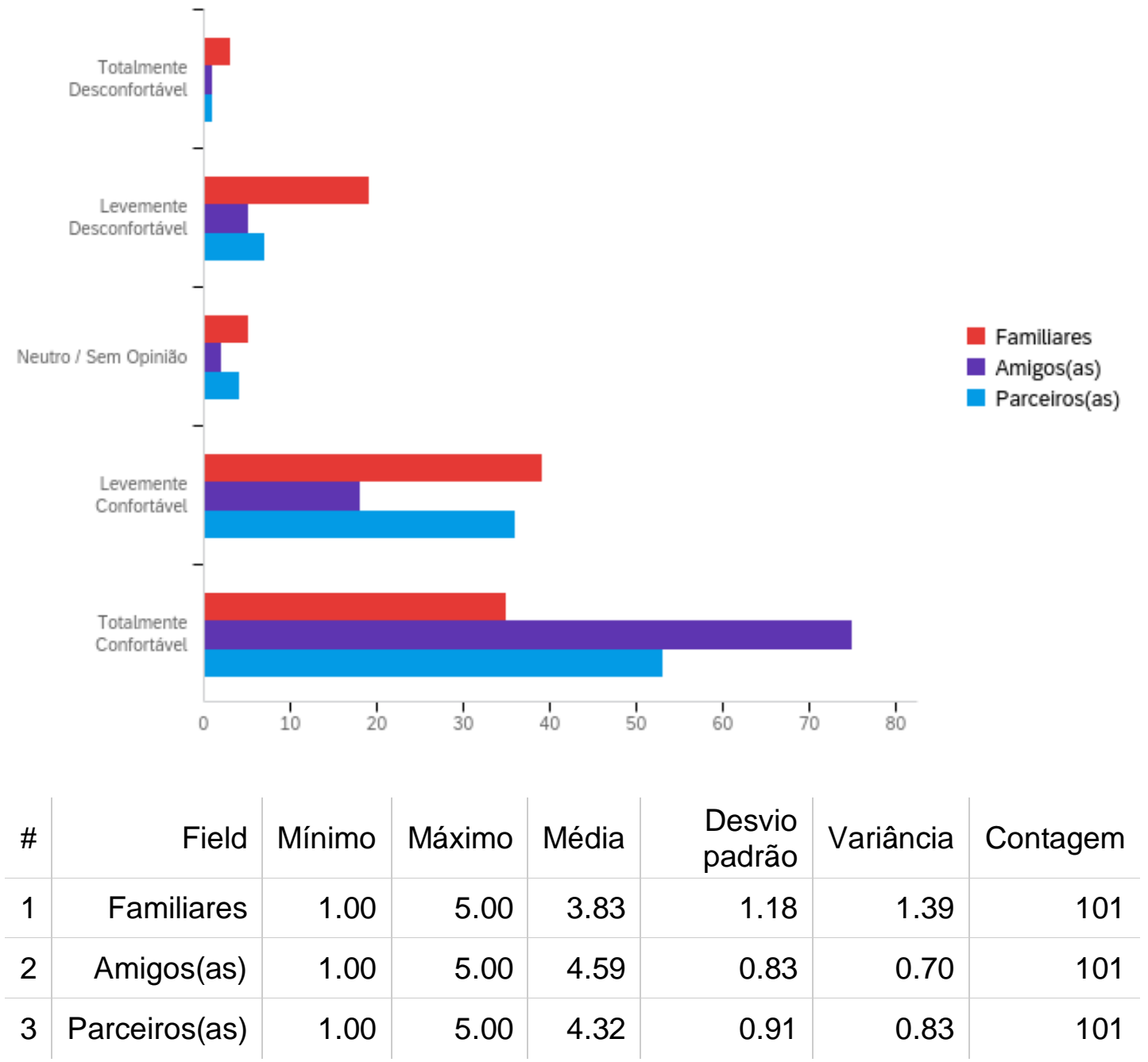




\begin{tabular}{|c|c|c|c|c|c|c|c|c|c|c|c|c|}
\hline \# & $\begin{array}{r}\text { Pergunt } \\
a\end{array}$ & $\begin{array}{r}\text { Totalme } \\
\text { nte } \\
\text { Desconf } \\
\text { ortável }\end{array}$ & & $\begin{array}{r}\text { Leveme } \\
\text { nte } \\
\text { Desconf } \\
\text { ortável }\end{array}$ & & $\begin{array}{c}\text { Neu } \\
\text { tro / } \\
\text { Sem } \\
\text { Opi } \\
\text { nião }\end{array}$ & & $\begin{array}{r}\text { Levem } \\
\text { ente } \\
\text { Confor } \\
\text { tável }\end{array}$ & & $\begin{array}{r}\text { Totalm } \\
\text { ente } \\
\text { Confor } \\
\text { tável }\end{array}$ & & To \\
\hline 1 & $\begin{array}{r}\text { Familiar } \\
\text { es }\end{array}$ & $2.97 \%$ & 3 & $18.81 \%$ & $\begin{array}{l}1 \\
9\end{array}$ & $\begin{array}{r}4.95 \\
\%\end{array}$ & 5 & $\begin{array}{r}38.61 \\
\%\end{array}$ & $\begin{array}{l}3 \\
9\end{array}$ & $\begin{array}{r}34.65 \\
\%\end{array}$ & $\begin{array}{l}3 \\
5\end{array}$ & \\
\hline$?$ & $\begin{array}{r}\text { Amigos } \\
\text { (as) }\end{array}$ & $0.99 \%$ & 1 & $4.95 \%$ & 5 & $\begin{array}{r}1.98 \\
\%\end{array}$ & 2 & $\begin{array}{r}17.82 \\
\%\end{array}$ & $\begin{array}{l}1 \\
8\end{array}$ & $\begin{array}{r}74.26 \\
\%\end{array}$ & $\begin{array}{l}7 \\
5\end{array}$ & $\begin{array}{r}10 \\
1\end{array}$ \\
\hline & $\begin{array}{r}\text { Parceir } \\
\text { os(as) }\end{array}$ & $0.99 \%$ & 1 & $6.93 \%$ & 7 & $\begin{array}{r}3.96 \\
\%\end{array}$ & 4 & $\begin{array}{r}35.64 \\
\%\end{array}$ & $\begin{array}{l}3 \\
6\end{array}$ & $\begin{array}{r}52.48 \\
\%\end{array}$ & $\begin{array}{l}5 \\
3\end{array}$ & 10 \\
\hline
\end{tabular}

Q10 - Marque na escala abaixo, o quanto você se sente confortável em falar sobre produtos eróticos com:

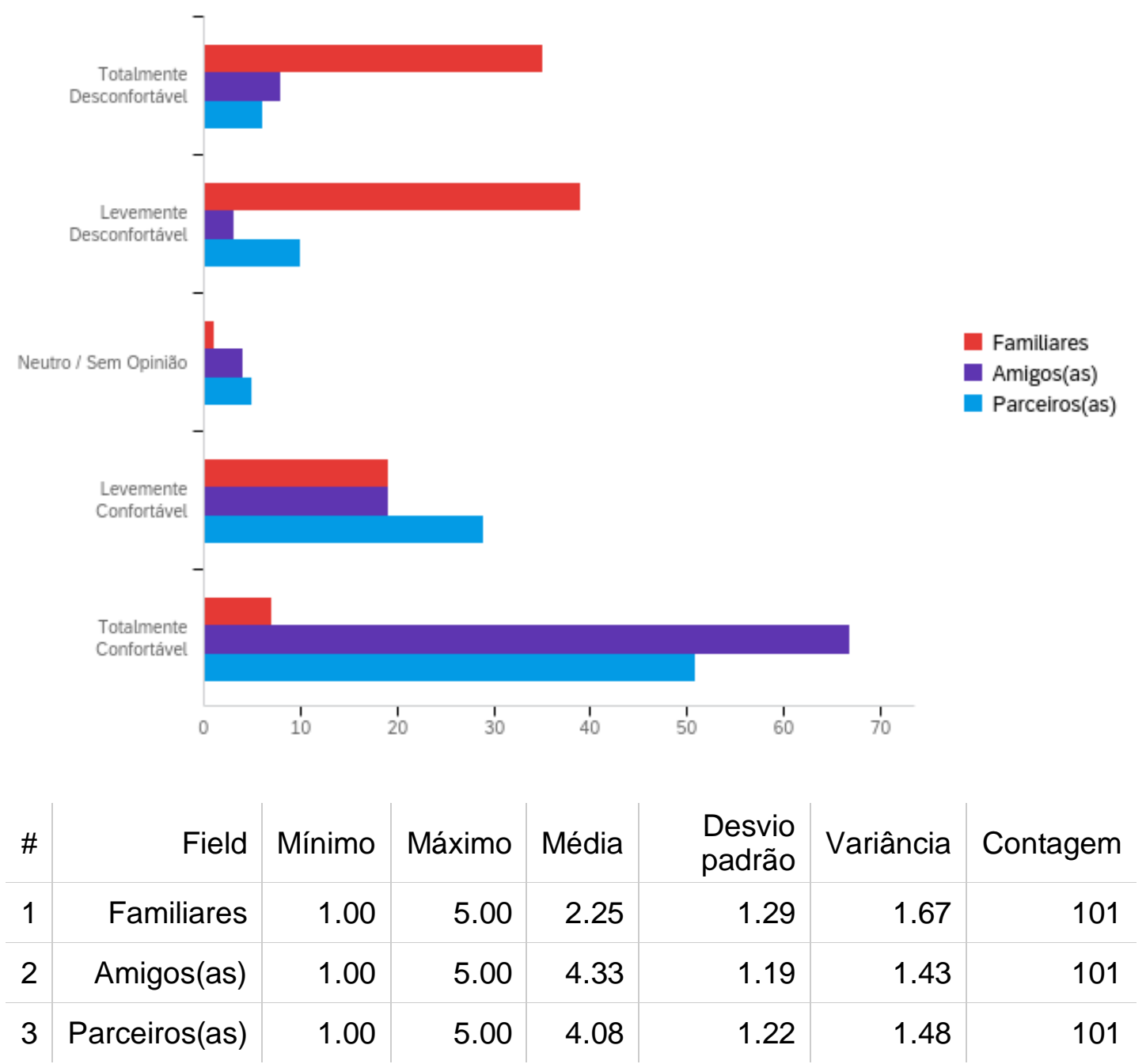




\begin{tabular}{|c|c|c|c|c|c|c|c|c|c|c|c|c|}
\hline & $\begin{array}{r}\text { Pergunt } \\
a\end{array}$ & $\begin{array}{r}\text { Totalme } \\
\text { nte } \\
\text { Desconf } \\
\text { ortável }\end{array}$ & & $\begin{array}{r}\text { Leveme } \\
\text { nte } \\
\text { Desconf } \\
\text { ortável }\end{array}$ & & $\begin{array}{l}\text { Neu } \\
\text { tro / } \\
\text { Sem } \\
\text { Opi } \\
\text { nião }\end{array}$ & & $\begin{array}{r}\text { Levem } \\
\text { ente } \\
\text { Confor } \\
\text { tável }\end{array}$ & & $\begin{array}{l}\text { Totalm } \\
\text { ente } \\
\text { Confor } \\
\text { tável }\end{array}$ & & \\
\hline 1 & $\begin{array}{r}\text { Familiar } \\
\text { es }\end{array}$ & $34.65 \%$ & 3 & $38.61 \%$ & $\begin{array}{l}3 \\
9\end{array}$ & $\begin{array}{r}0.99 \\
\%\end{array}$ & 1 & $\begin{array}{r}18.81 \\
\%\end{array}$ & $\begin{array}{l}1 \\
9\end{array}$ & $6.93 \%$ & 7 & $\begin{array}{r}10 \\
1\end{array}$ \\
\hline 2 & $\begin{array}{r}\text { Amigos } \\
\text { (as) }\end{array}$ & $7.92 \%$ & 8 & $2.97 \%$ & 3 & $\begin{array}{r}3.96 \\
\%\end{array}$ & 4 & $\begin{array}{r}18.81 \\
\%\end{array}$ & $\begin{array}{l}1 \\
9\end{array}$ & $\begin{array}{r}66.34 \\
\%\end{array}$ & $\begin{array}{l}6 \\
7\end{array}$ & 10 \\
\hline 3 & $\begin{array}{r}\text { Parceir } \\
\text { os(as) }\end{array}$ & & 6 & $9.90 \%$ & $\begin{array}{l}1 \\
0\end{array}$ & $\begin{array}{r}4.95 \\
\%\end{array}$ & 5 & $\begin{array}{r}28.71 \\
\%\end{array}$ & $\begin{array}{l}2 \\
9\end{array}$ & $\begin{array}{r}50.50 \\
\%\end{array}$ & $\begin{array}{l}5 \\
1\end{array}$ & 10 \\
\hline
\end{tabular}

Q11 - Já EXPERIMENTOU algum produto erótico?
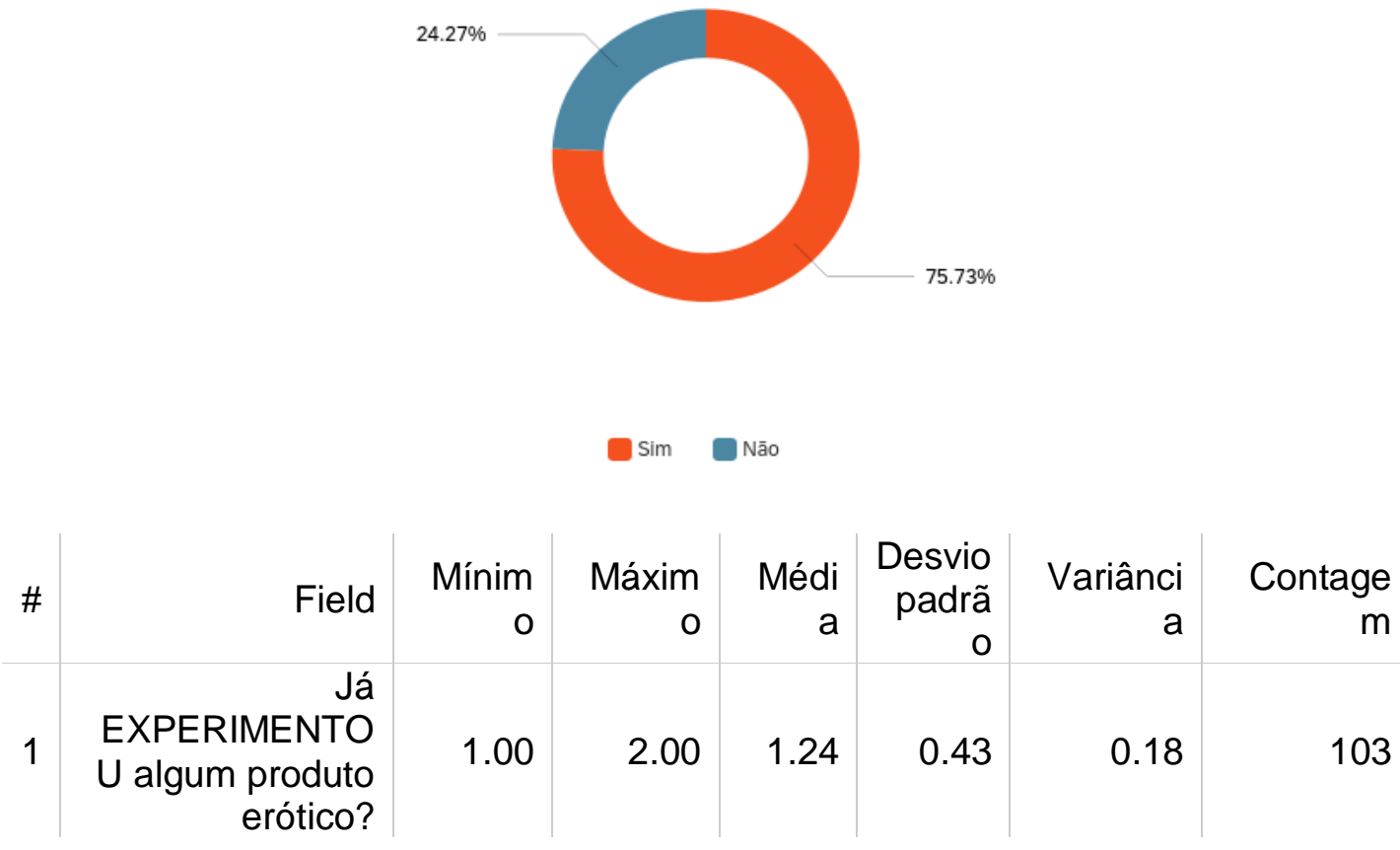

\begin{tabular}{|r|r|r|r}
$\#$ & Resposta & $\%$ & Contagem \\
\hline 1 & Sim & $75.73 \%$ & 78 \\
\hline 2 & Não & $24.27 \%$ & 25 \\
\hline & Total & $100 \%$ & 103
\end{tabular}


Q12 - Se sim, utilizaria novamente?

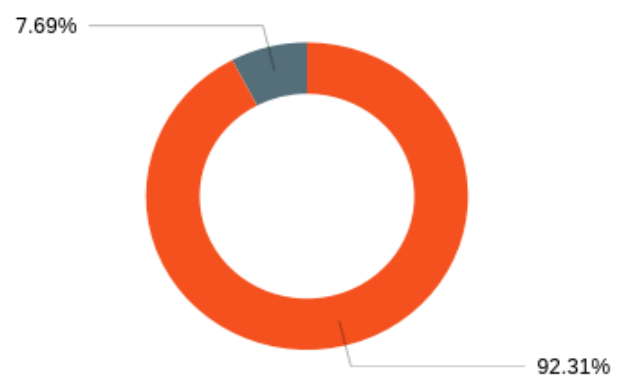

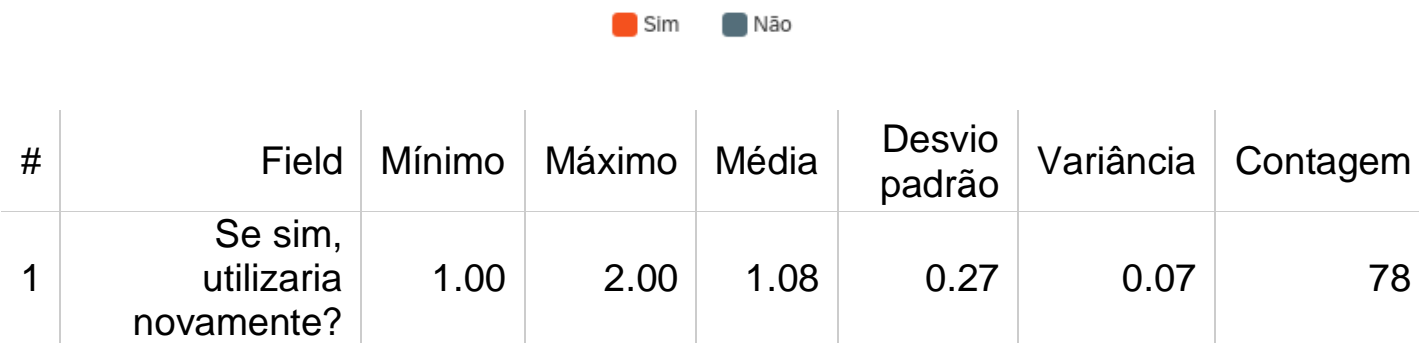

\begin{tabular}{|r|r|r|r}
$\#$ & Resposta & $\%$ & Contagem \\
\hline 1 & Sim & $92.31 \%$ & 72 \\
\hline 2 & Não & $7.69 \%$ & 6 \\
\hline & Total & $100 \%$ & 78
\end{tabular}

Q13 - Qual(is) produto(s) já experimentou?

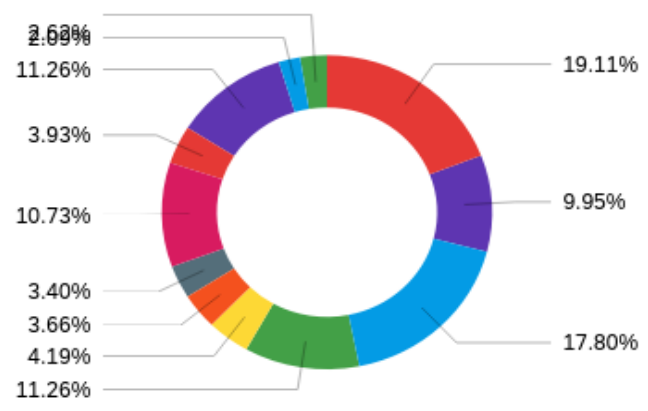

Lingerie Fantasia óleo, Gel, Lubrificante e afins Bolinhas de Gel

Bolinhas de Pompoar Sugador Bullet Vibrador ou Dildo Plug Anal

Algemas, Amarras ou semelhantes Strapon Outros 


\begin{tabular}{|l|r|r|r}
\hline$\#$ & Resposta & $\%$ & Contagem \\
\hline 1 & Lingerie & $19.11 \%$ & 73 \\
\hline 2 & Fantasia & $9.95 \%$ & 38 \\
\hline 3 & Óleo, Gel, Lubrificante e afins & $17.80 \%$ & 68 \\
\hline 4 & Bolinhas de Gel & $11.26 \%$ & 43 \\
\hline 5 & Bolinhas de Pompoar & $4.19 \%$ & 16 \\
\hline 6 & Sugador & $3.66 \%$ & 14 \\
\hline 7 & Bullet & $3.40 \%$ & 13 \\
\hline 8 & Vibrador ou Dildo & $10.73 \%$ & 41 \\
\hline 9 & Plug Anal & $3.93 \%$ & 15 \\
\hline 10 & Algemas, Amarras ou semelhantes & $11.26 \%$ & 43 \\
\hline 11 & Strapon & $2.09 \%$ & 8 \\
\hline 12 & Outros & $2.62 \%$ & 10 \\
\hline & Total & $100 \%$ & 382 \\
\hline
\end{tabular}

Q14 - Se não, tem interesse de experimentar?

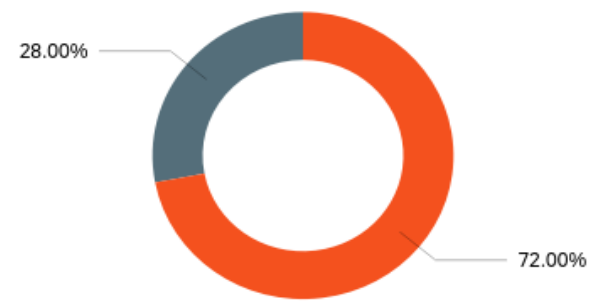

\begin{tabular}{|c|c|c|c|c|c|c|c|}
\hline \# & Field & Mínimo & Máximo & Média & $\begin{array}{l}\text { Desvio } \\
\text { padrão }\end{array}$ & Variância & Contagem \\
\hline 1 & $\begin{array}{r}\text { Se não, tem } \\
\text { interesse de } \\
\text { experimentar? }\end{array}$ & 1.00 & 2.00 & 1.28 & 0.45 & 0.20 & 25 \\
\hline
\end{tabular}

\begin{tabular}{l|r|r|r}
$\#$ & Resposta & $\%$ & Contagem \\
\hline 1 & $\operatorname{Sim}$ & $72.00 \%$ & 18
\end{tabular}




\begin{tabular}{|r|r|r|r|}
\hline 2 & Não & $28.00 \%$ & 7 \\
\hline & Total & $100 \%$ & 25
\end{tabular}

Q15 - Qual(is) produto(s) tem interesse de experimentar?

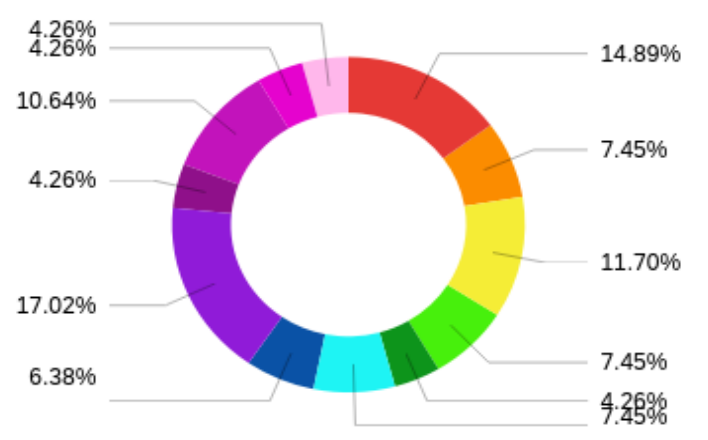

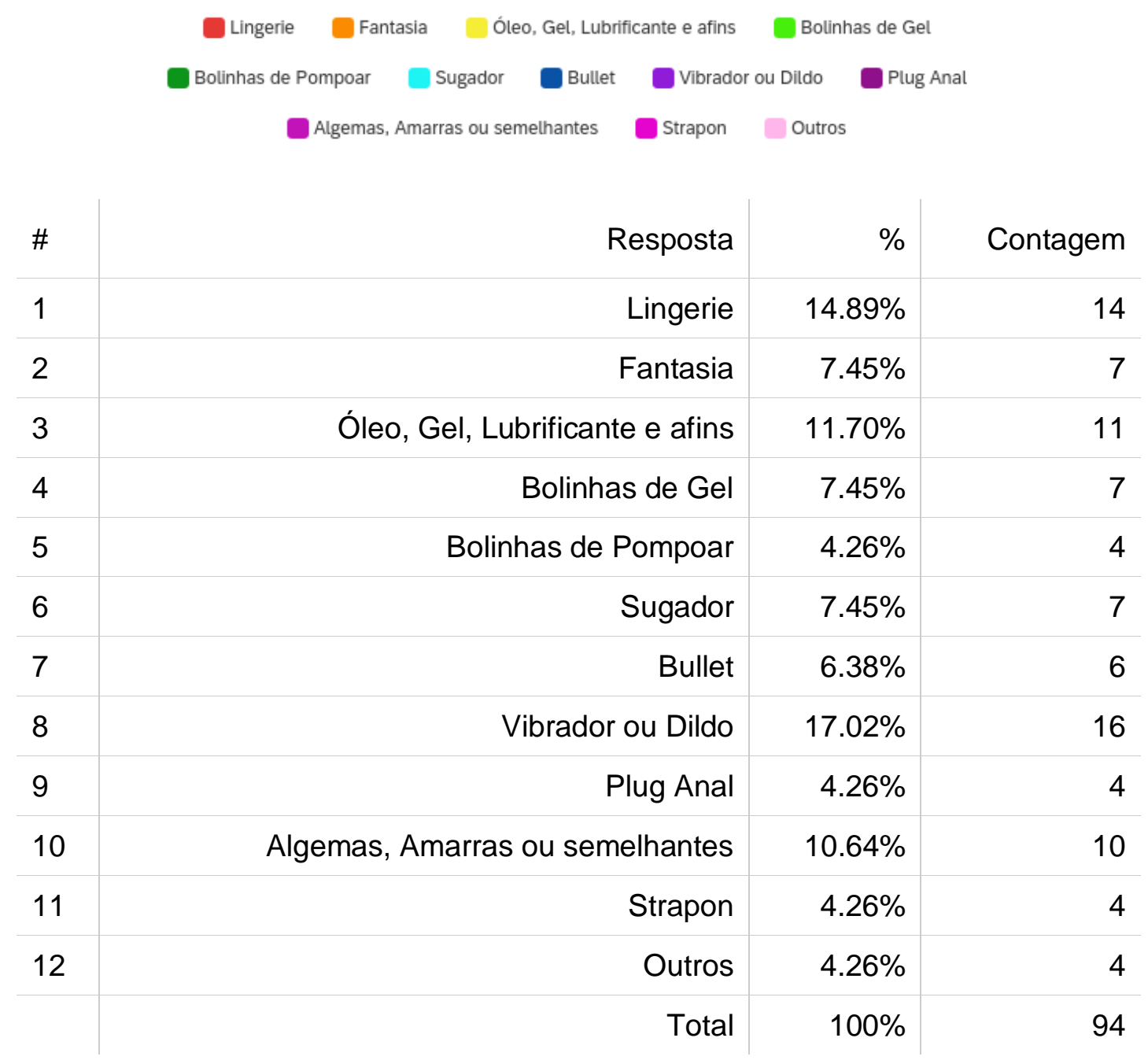


Q16 - Você já COMPROU algum produto erótico?
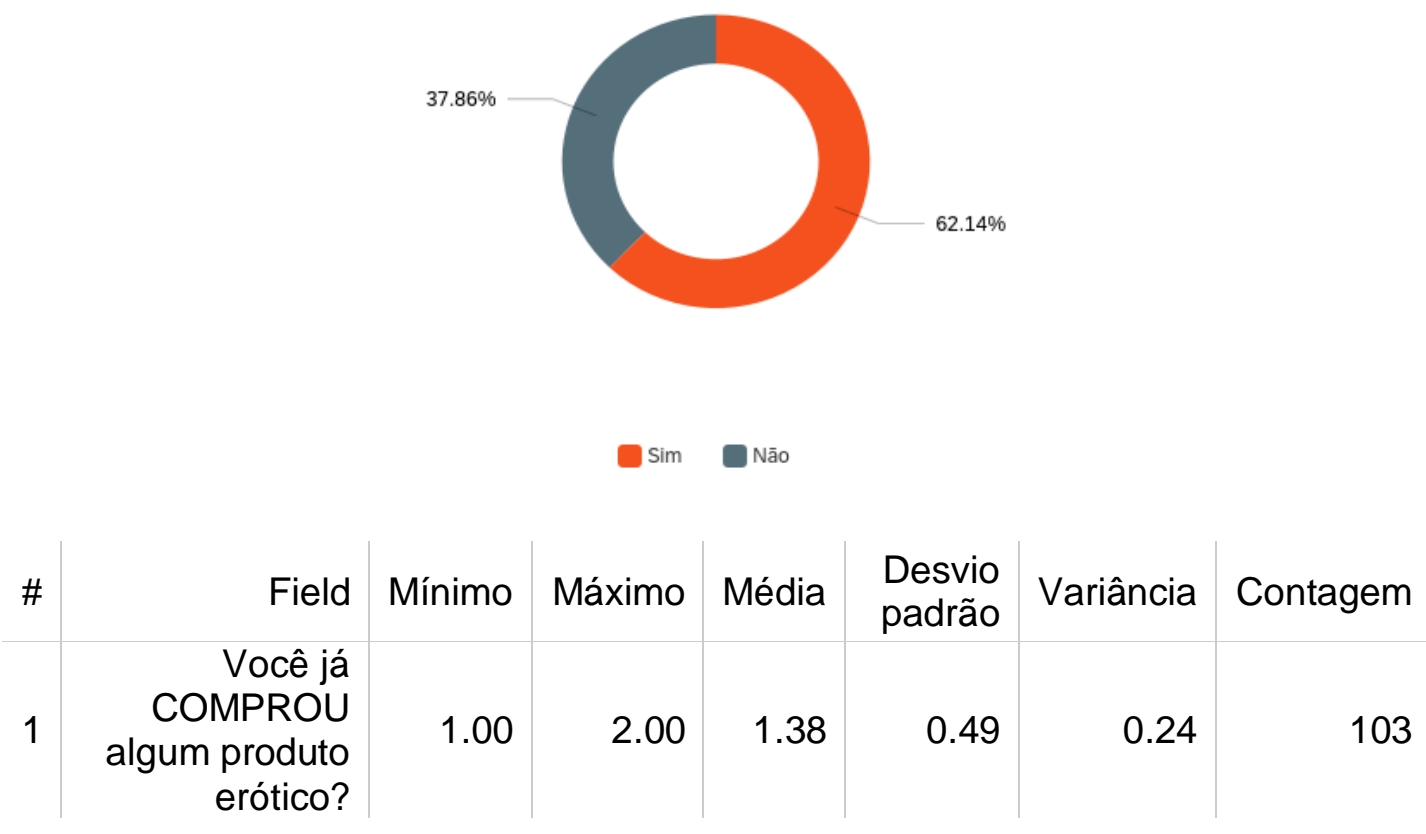

\begin{tabular}{|r|r|r|r}
\hline$\#$ & Resposta & $\%$ & Contagem \\
\hline 1 & Sim & $62.14 \%$ & 64 \\
\hline 2 & Não & $37.86 \%$ & 39 \\
\hline & Total & $100 \%$ & 103
\end{tabular}

Q17 - Se sim, compraria novamente?

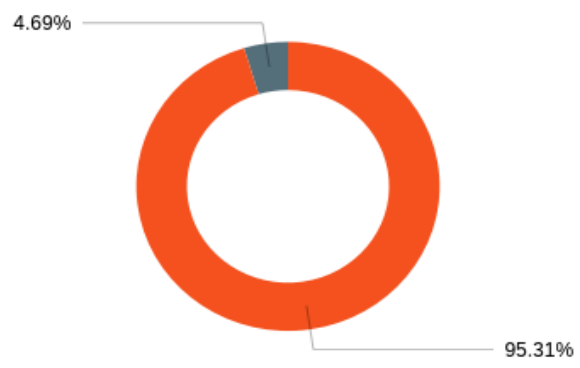

Sim Nāo 


\begin{tabular}{|c|c|c|c|c|c|c|c|}
\hline \# & Field & Mínimo & Máximo & Média & $\begin{array}{l}\text { Desvio } \\
\text { padrão }\end{array}$ & Variância & Contagem \\
\hline 1 & $\begin{array}{r}\text { Se sim, } \\
\text { compraria } \\
\text { novamente? }\end{array}$ & 1.00 & 2.00 & 1.05 & 0.21 & 0.04 & 64 \\
\hline
\end{tabular}

\begin{tabular}{|r|r|r|r}
$\#$ & Resposta & $\%$ & Contagem \\
\hline 1 & Sim & $95.31 \%$ & 61 \\
\hline 2 & Não & $4.69 \%$ & 3 \\
\hline & Total & $100 \%$ & 64
\end{tabular}

Q18 - Qual(is) motivo(s) te leva(m) a COMPRAR produtos eróticos?

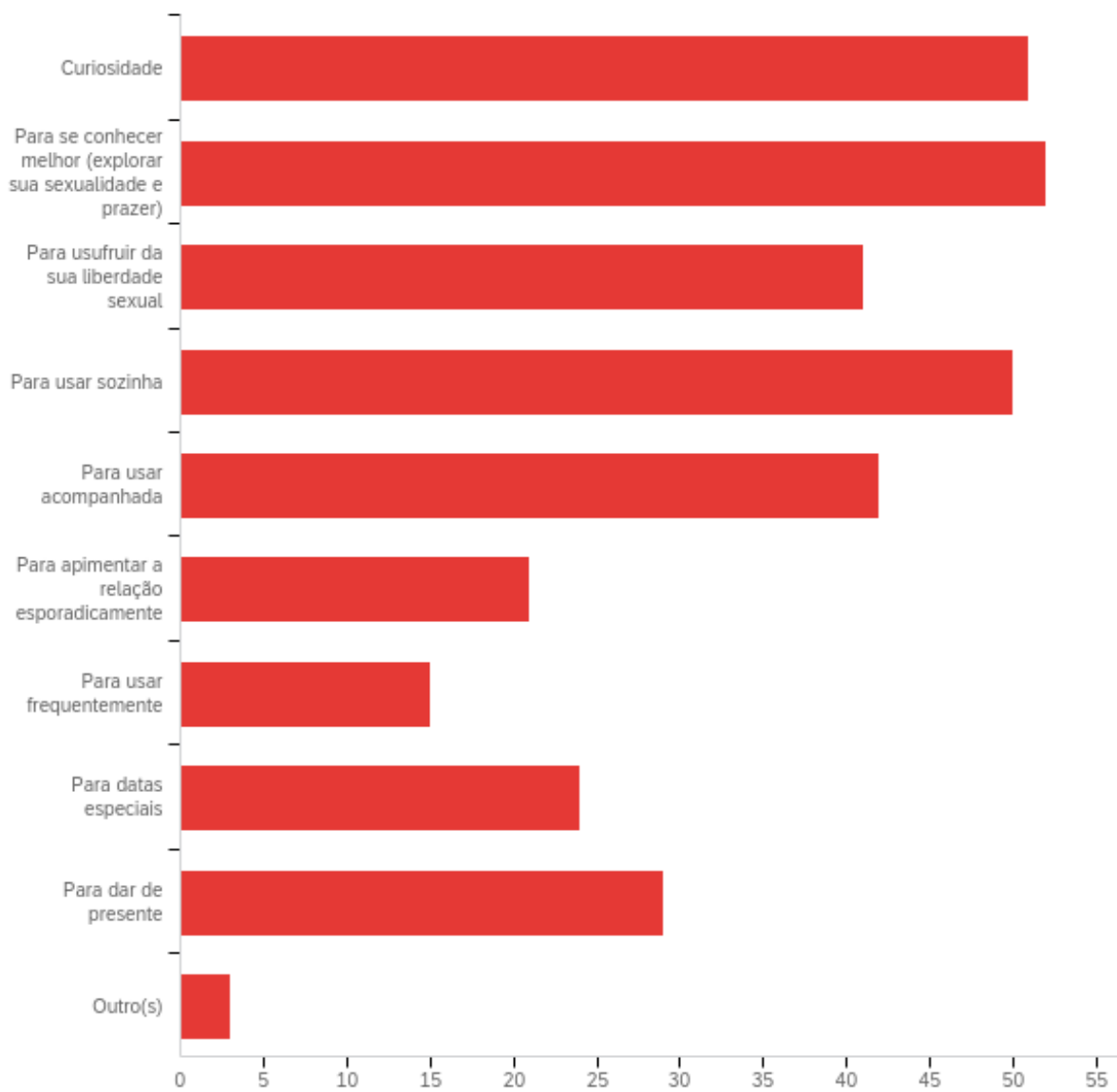

\begin{tabular}{|l|r|r|r|}
\hline$\#$ & Resposta & $\%$ & Contagem \\
\hline 1 & Curiosidade & $15.55 \%$ & 51 \\
\hline 2 & Para se conhecer melhor (explorar sua sexualidade e & $15.85 \%$ & 52 \\
prazer) & 15.85 & 41 \\
\hline 3 & Para usufruir da sua liberdade sexual & $12.50 \%$ & 41 \\
\hline
\end{tabular}




\begin{tabular}{|l|r|r|r|}
\hline 4 & Para usar sozinha & $15.24 \%$ & 50 \\
\hline 5 & Para usar acompanhada & $12.80 \%$ & 42 \\
\hline 6 & Para apimentar a relação esporadicamente & $6.40 \%$ & 21 \\
\hline 7 & Para usar frequentemente & $4.57 \%$ & 15 \\
\hline 8 & Para datas especiais & $7.32 \%$ & 24 \\
\hline 9 & Para dar de presente & $8.84 \%$ & 29 \\
\hline 10 & Outro(s) & $0.91 \%$ & 3 \\
\hline & Total & $100 \%$ & 328 \\
\hline
\end{tabular}

Q19 - Se não, compraria?
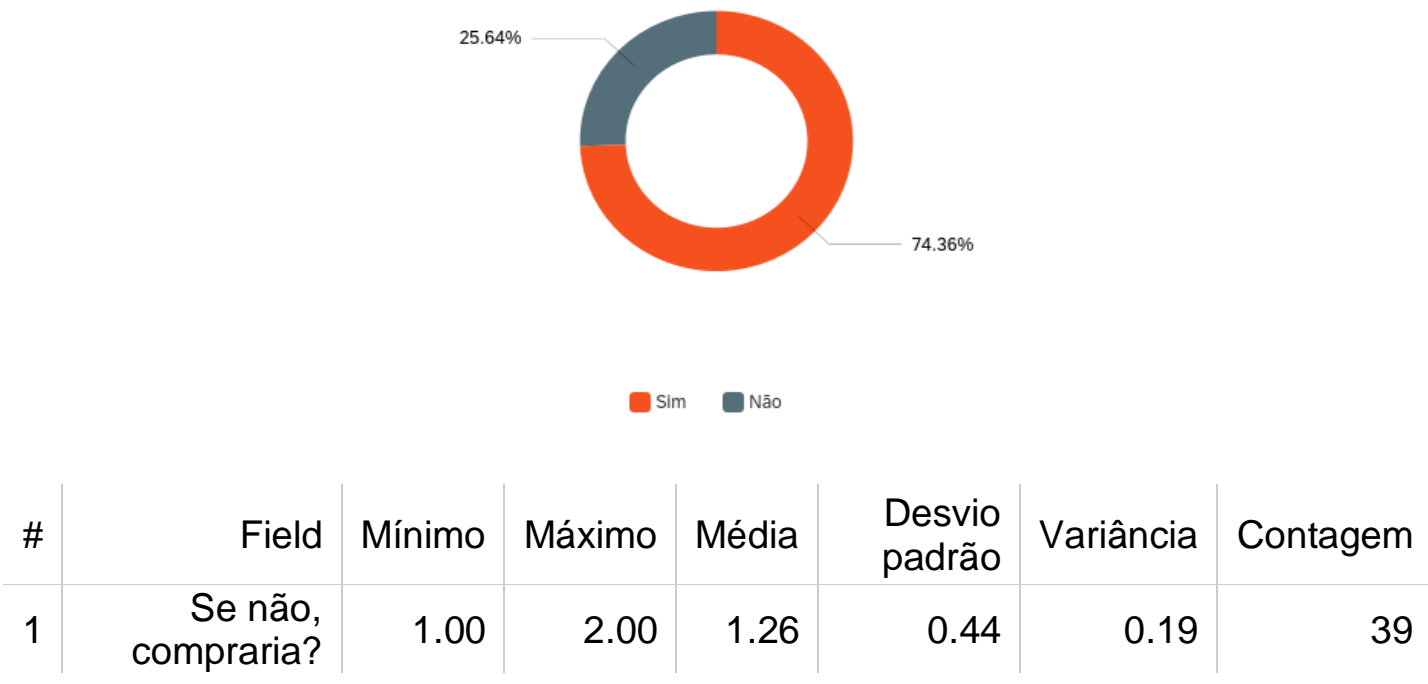

\begin{tabular}{|r|r|r|r}
\hline$\#$ & Resposta & $\%$ & Contagem \\
\hline 1 & Sim & $74.36 \%$ & 29 \\
\hline 2 & Não & $25.64 \%$ & 10 \\
\hline & Total & $100 \%$ & 39
\end{tabular}


Q20 - Algo te inibe na compra de produtos eróticos?

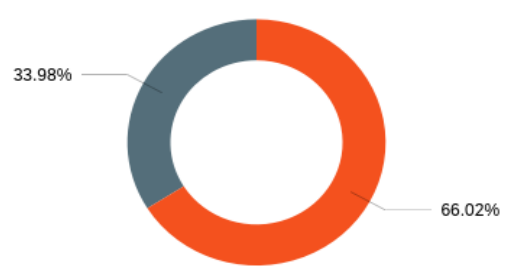

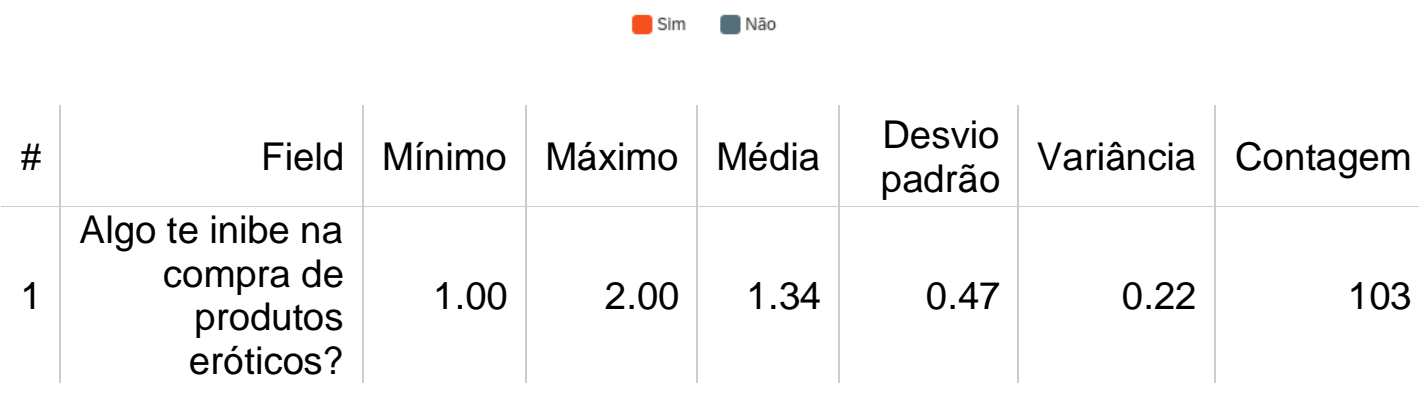

\begin{tabular}{|r|r|r|r}
$\#$ & Resposta & $\%$ & Contagem \\
\hline 1 & Sim & $66.02 \%$ & 68 \\
\hline 2 & Não & $33.98 \%$ & 35 \\
\hline & Total & $100 \%$ & 103
\end{tabular}


Q21 - Se sim, qual(is) o(s) motivo(s)?

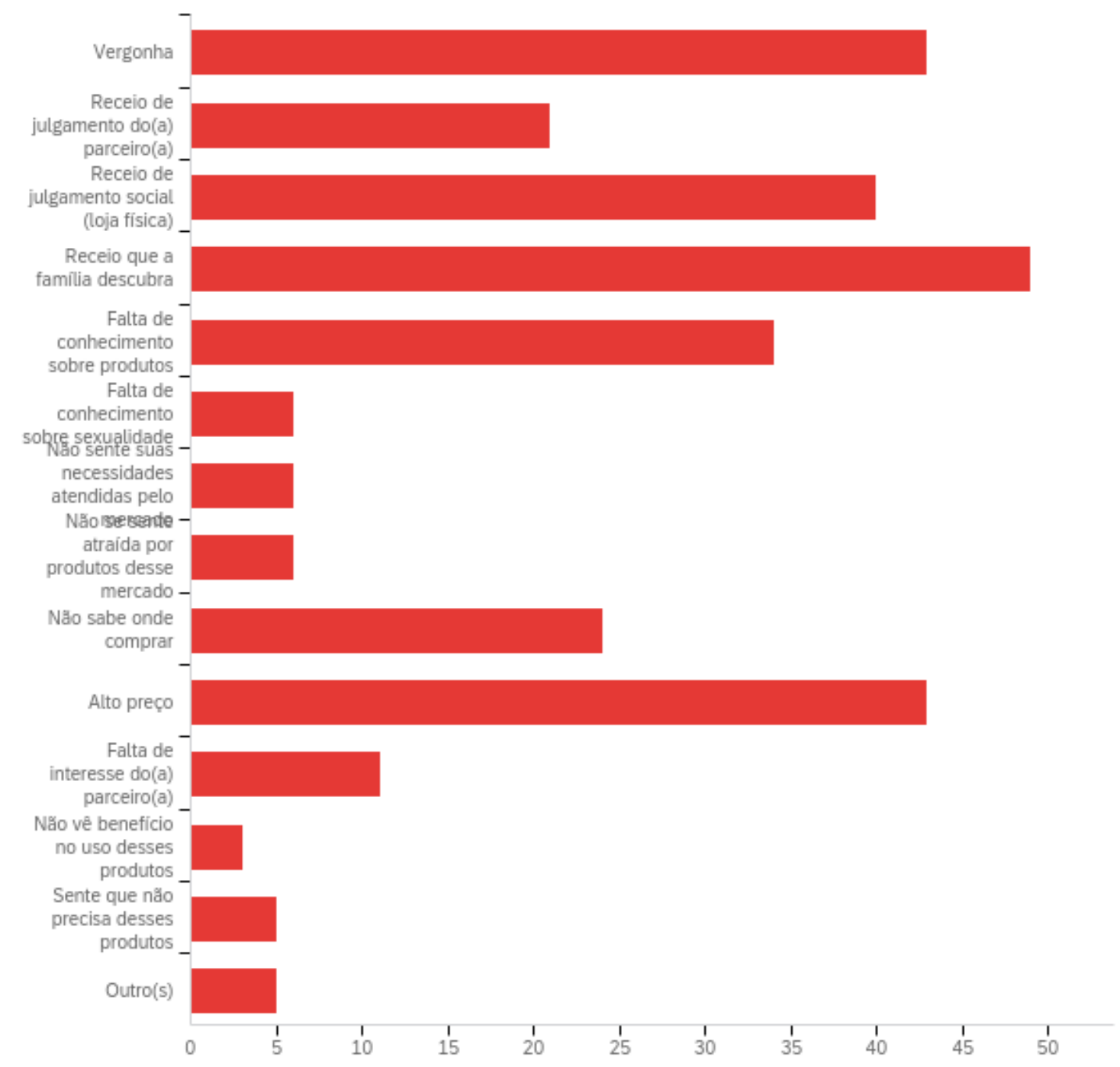

\begin{tabular}{|l|r|r|r}
\hline$\#$ & Resposta & $\%$ & Contagem \\
\hline 1 & Vergonha & $14.53 \%$ & 43 \\
\hline 2 & Receio de julgamento do(a) parceiro(a) & $7.09 \%$ & 21 \\
\hline 3 & Receio de julgamento social (loja física) & $13.51 \%$ & 40 \\
\hline 4 & Receio que a família descubra & $16.55 \%$ & 49 \\
\hline 5 & Falta de conhecimento sobre produtos & $11.49 \%$ & 34 \\
\hline 6 & Falta de conhecimento sobre sexualidade & $2.03 \%$ & 6 \\
\hline 7 & Não sente suas necessidades atendidas pelo mercado & $2.03 \%$ & 6 \\
\hline 8 & Não se sente atraída por produtos desse mercado & $2.03 \%$ & 6 \\
\hline 9 & Não sabe onde comprar & $8.11 \%$ & 24 \\
\hline 10 & Alto preço & $14.53 \%$ & 43 \\
\hline
\end{tabular}




\begin{tabular}{|r|r|r|r}
\hline 11 & Falta de interesse do(a) parceiro(a) & $3.72 \%$ & 11 \\
\hline 12 & Não vê benefício no uso desses produtos & $1.01 \%$ & 3 \\
\hline 13 & Sente que não precisa desses produtos & $1.69 \%$ & 5 \\
\hline 14 & Outro(s) & $1.69 \%$ & 5 \\
\hline & Total & $100 \%$ & 296 \\
\hline
\end{tabular}

Q22 - Qual(is) fonte(s) você utiliza para obter informações sobre produtos eróticos?

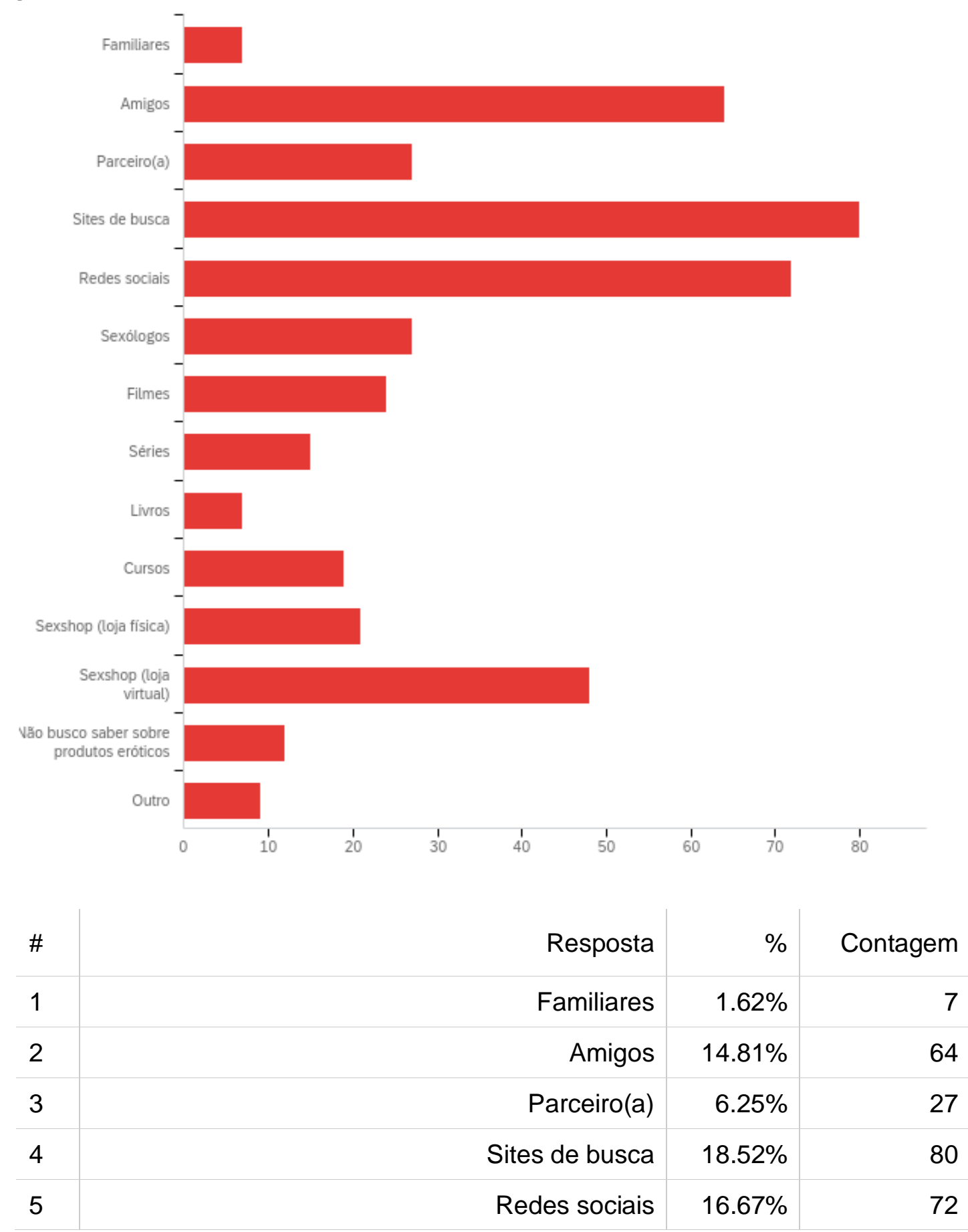




\begin{tabular}{|l|r|r|r}
\hline 6 & Sexólogos & $6.25 \%$ & 27 \\
\hline 7 & Filmes & $5.56 \%$ & 24 \\
\hline 8 & Séries & $3.47 \%$ & 15 \\
\hline 9 & Livros & $1.62 \%$ & 7 \\
\hline 10 & Cursos & $4.40 \%$ & 19 \\
\hline 11 & Sexshop (loja física) & $4.86 \%$ & 21 \\
\hline 12 & Sexshop (loja virtual) & $11.11 \%$ & 48 \\
\hline 13 & Não busco saber sobre produtos eróticos & $2.78 \%$ & 12 \\
\hline 14 & Outro & $2.08 \%$ & 9 \\
\hline & Total & $100 \%$ & 432 \\
\hline
\end{tabular}

Q23 - Qual pauta você mais encontra dentro do seu círculo social?

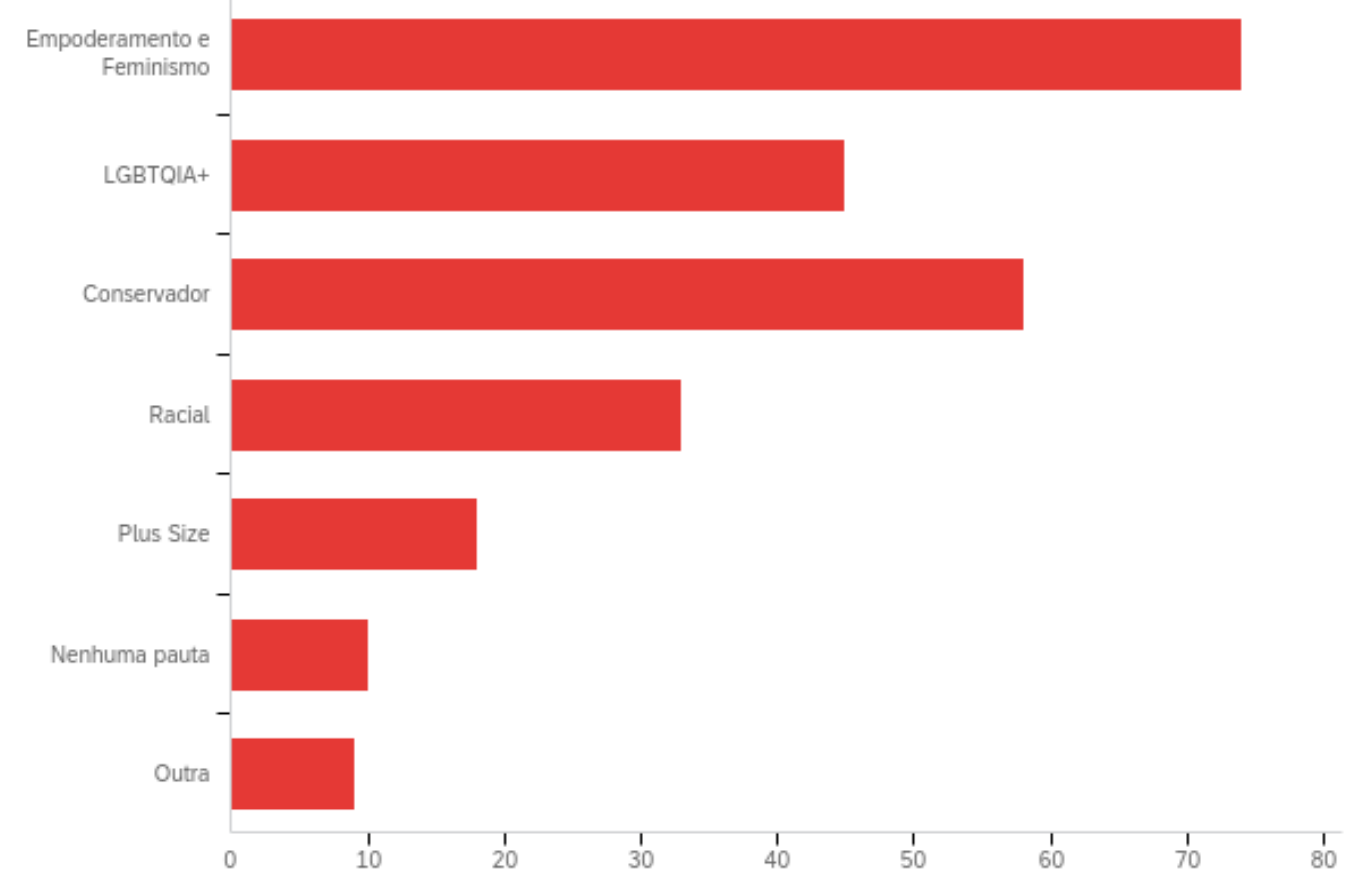

\begin{tabular}{|l|r|r|r}
$\#$ & Resposta & $\%$ & Contagem \\
\hline 1 & Empoderamento e Feminismo & $29.96 \%$ & 74 \\
\hline 3 & LGBTQIA+ & $18.22 \%$ & 45 \\
\hline 4 & Conservador & $23.48 \%$ & 58 \\
\hline 5 & Racial & $13.36 \%$ & 33 \\
\hline 6 & Plus Size & $7.29 \%$ & 18 \\
\hline
\end{tabular}




\begin{tabular}{|l|r|r|r}
\hline 7 & Nenhuma pauta & $4.05 \%$ & 10 \\
\hline 8 & Outra & $3.64 \%$ & 9 \\
\hline & Total & $100 \%$ & 247 \\
\hline
\end{tabular}

Q24 - Sexualmente ativo?

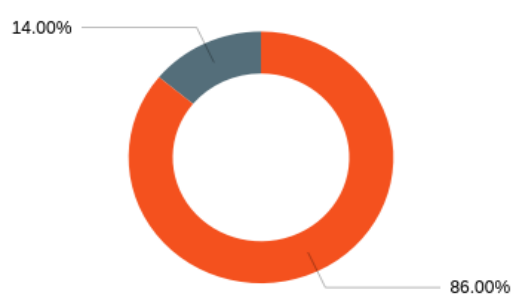

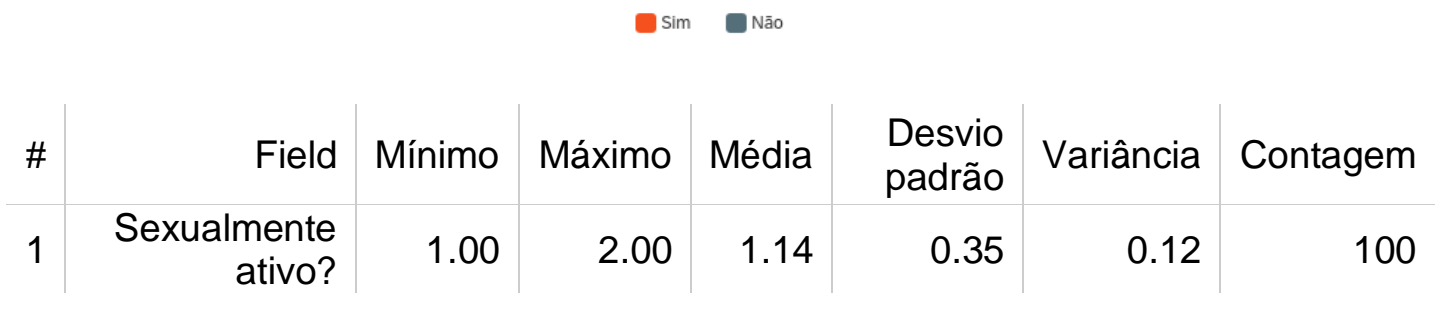

\begin{tabular}{|r|r|r|r}
\hline$\#$ & Resposta & $\%$ & Contagem \\
\hline 1 & Sim & $86.00 \%$ & 86 \\
\hline 2 & Não & $14.00 \%$ & 14 \\
\hline & Total & $100 \%$ & 100
\end{tabular}

Q25 - No período de 1 ano, o quanto você destinaria a compra de produtos eróticos?

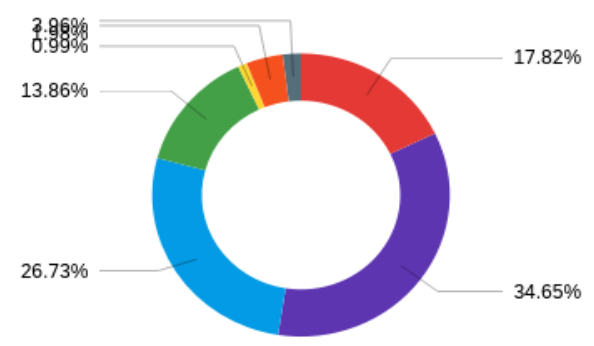

Nāo destinaria nenhum valor para esses produtos.

Até $\mathrm{R} \$ 100,00$. De $\$ \$ 100,00$ a R $\$ 300,00$.

De $R \$ 300,00$ a $R \$ 500,00$. De $R \$ 500,00$ a R $\$ 700,00$.

De $\mathrm{R} \$ 700,00$ a $\mathrm{R} \$ 1000,00$.

Acima de $\mathrm{R} \$ 1000,00$. 


\begin{tabular}{|c|c|c|c|c|c|c|c|}
\hline \# & Field & Mínimo & Máximo & Média & $\begin{array}{l}\text { Desvio } \\
\text { padrão }\end{array}$ & Variância & Contagem \\
\hline & $\begin{array}{r}\text { No período de } 1 \\
\text { ano, o quanto } \\
\text { você destinaria } \\
\text { a compra de } \\
\text { produtos } \\
\text { eróticos? }\end{array}$ & 1.00 & 7.00 & 2.65 & 1.34 & 1.79 & 101 \\
\hline
\end{tabular}

\begin{tabular}{|r|r|r|r|}
\hline$\#$ & Resposta & $\%$ & Contagem \\
\hline 1 & Não destinaria nenhum valor para esses produtos. & $17.82 \%$ & 18 \\
\hline 2 & Até $\mathrm{R} \$ 100,00$. & $34.65 \%$ & 35 \\
\hline 3 & De $\mathrm{R} \$ 100,00$ a $\mathrm{R} \$ 300,00$. & $26.73 \%$ & 27 \\
\hline 4 & De $\mathrm{R} \$ 300,00$ a $\mathrm{R} \$ 500,00$. & $13.86 \%$ & 14 \\
\hline 5 & De $\mathrm{R} \$ 500,00$ a $\mathrm{R} \$ 700,00$. & $0.99 \%$ & 1 \\
\hline 6 & De $\mathrm{R} \$ 700,00$ a $\mathrm{R} \$ 1000,00$. & $3.96 \%$ & 4 \\
\hline 7 & Acima de $\mathrm{R} \$ 1000,00$. & $1.98 \%$ & 2 \\
\hline & Total & $100 \%$ & 101 \\
\hline
\end{tabular}

Q26 - Você se identifica como:

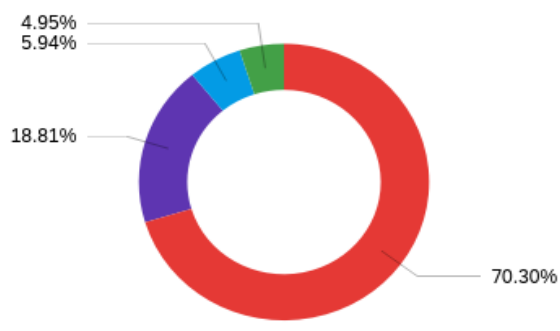

Heterossexual

Homossexual

Outro

\begin{tabular}{|c|c|c|c|c|c|c|c|}
\hline \# & Field & Mínimo & Máximo & Média & $\begin{array}{l}\text { Desvio } \\
\text { padrão }\end{array}$ & Variância & Contagem \\
\hline 1 & $\begin{array}{r}\text { Você se } \\
\text { identifica } \\
\text { como: }\end{array}$ & 1.00 & 4.00 & 1.46 & 0.81 & 0.66 & 101 \\
\hline
\end{tabular}




\begin{tabular}{|l|r|r|r|}
\hline$\#$ & Resposta & $\%$ & Contagem \\
\hline 1 & Heterossexual & $70.30 \%$ & 71 \\
\hline 2 & Bissexual & $18.81 \%$ & 19 \\
\hline 3 & Homossexual & $5.94 \%$ & 6 \\
\hline 4 & Outro & $4.95 \%$ & 5 \\
\hline & Total & $100 \%$ & 101 \\
\hline
\end{tabular}

Q27 - Atualmente você se encontra:

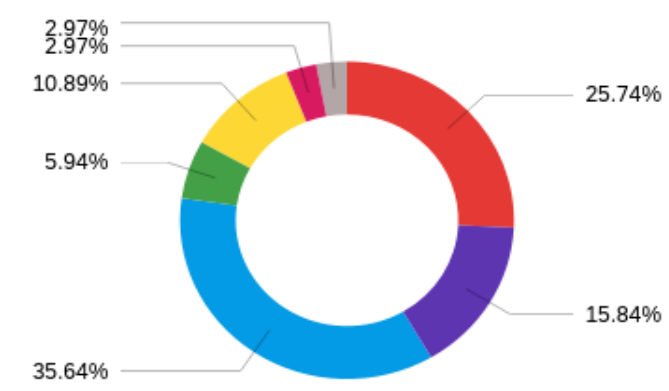

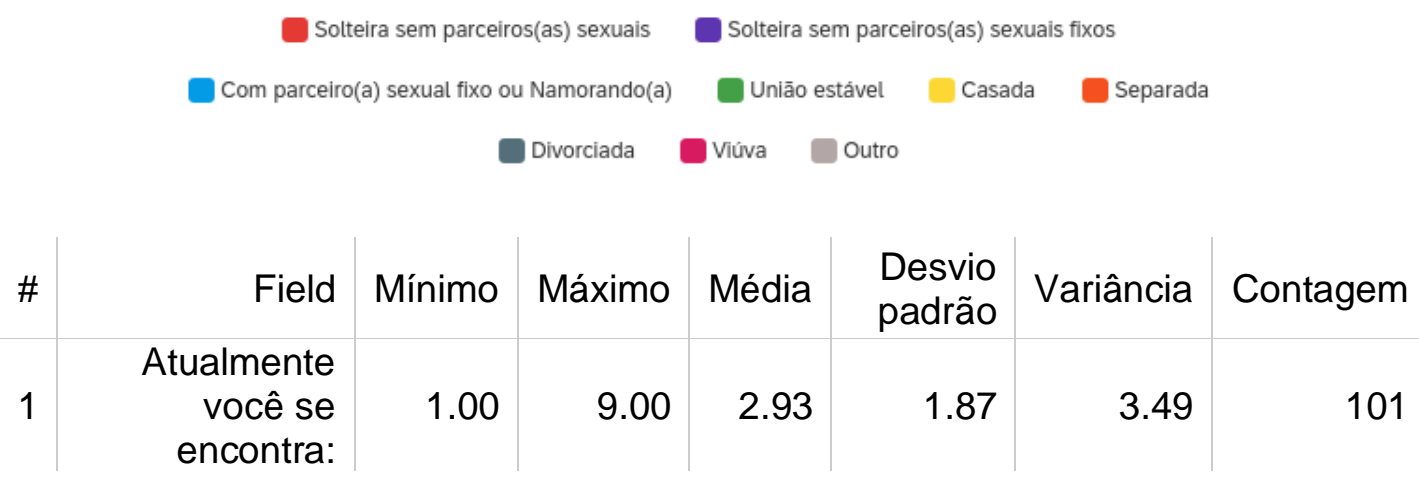

\begin{tabular}{|r|r|r|r}
\hline$\#$ & Resposta & $\%$ & Contagem \\
\hline 1 & Solteira sem parceiros(as) sexuais & $25.74 \%$ & 26 \\
\hline 2 & Solteira sem parceiros(as) sexuais fixos & $15.84 \%$ & 16 \\
\hline 3 & Com parceiro(a) sexual fixo ou Namorando(a) & $35.64 \%$ & 36 \\
\hline 4 & União estável & $5.94 \%$ & 6 \\
\hline 5 & Casada & $10.89 \%$ & 11 \\
\hline 6 & Separada & $0.00 \%$ & 0 \\
\hline
\end{tabular}




\begin{tabular}{|r|r|r|r}
\hline 7 & Divorciada & $0.00 \%$ & 0 \\
\hline 8 & Viúva & $2.97 \%$ & 3 \\
\hline 9 & Outro & $2.97 \%$ & 3 \\
\hline & Total & $100 \%$ & 101 \\
\hline
\end{tabular}

Q28 - Indique sua idade:
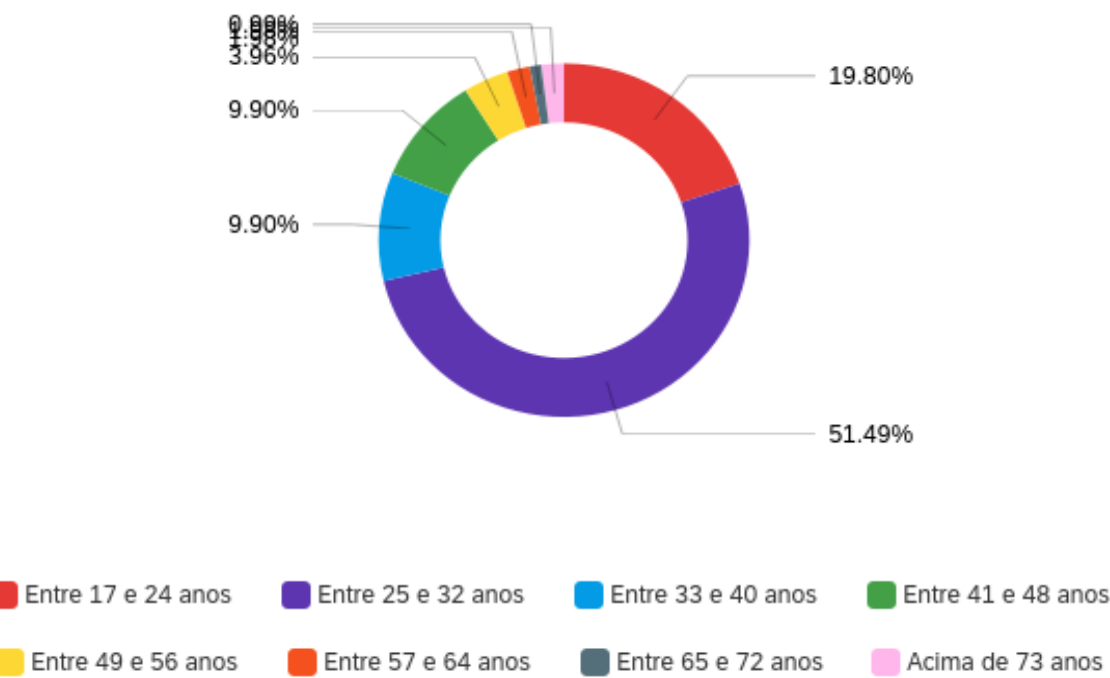

\begin{tabular}{|r|r|r|r|r|r|r|r|} 
\# & Campo & Mínimo & Máximo & Média & $\begin{array}{r}\text { Desvio } \\
\text { padrão }\end{array}$ & Variância & Contagem \\
\hline 1 & $\begin{array}{r}\text { Indique sua } \\
\text { idade: }\end{array}$ & 1.00 & 8.00 & 2.47 & 1.45 & 2.11 & 101 \\
\hline
\end{tabular}

\begin{tabular}{|l|r|r|r|}
\hline$\#$ & Resposta & $\%$ & Contagem \\
\hline 7 & Entre 65 e 72 anos & $0.99 \%$ & 1 \\
\hline 6 & Entre 57 e 64 anos & $1.98 \%$ & 2 \\
\hline 5 & Entre 49 e 56 anos & $3.96 \%$ & 4 \\
\hline 4 & Entre 41 e 48 anos & $9.90 \%$ & 10 \\
\hline 3 & Entre 33 e 40 anos & $9.90 \%$ & 10 \\
\hline 2 & Entre 25 e 32 anos & $51.49 \%$ & 52 \\
\hline 1 & Entre 17 e 24 anos & $19.80 \%$ & 20 \\
\hline 8 & Acima de 73 anos & $1.98 \%$ & 2 \\
\hline & Total & $100 \%$ & 101 \\
\hline
\end{tabular}




\section{Q29 - Qual o seu Grau de Escolaridade?}

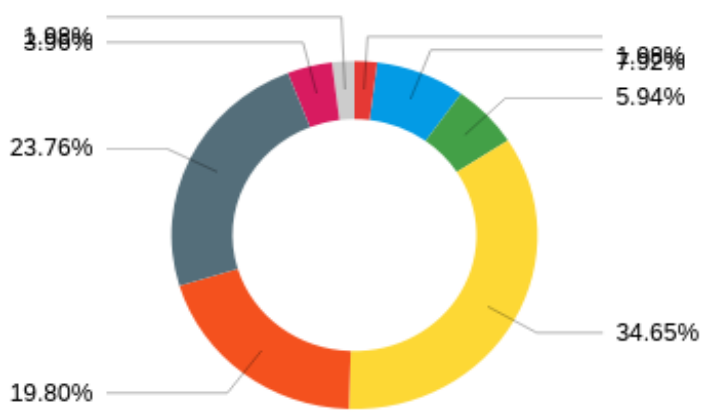

Primeiro Grau Completo

Primeiro Grau Incompleto

Ensino Médio Completo

Ensino Médio Incompleto

Graduaçāo Completo

Graduaçāo Incompleto

Pós Graduaçāo

Mestrado Doutorado

\begin{tabular}{|c|c|c|c|c|c|c|c|}
\hline \# & Field & Mínimo & Máximo & Média & $\begin{array}{l}\text { Desvio } \\
\text { padrão }\end{array}$ & Variância & Contagem \\
\hline 1 & $\begin{array}{r}\text { Qual o seu } \\
\text { Grau de } \\
\text { Escolaridade? }\end{array}$ & 1.00 & 9.00 & 5.57 & 1.48 & 2.19 & 101 \\
\hline
\end{tabular}

\begin{tabular}{|l|r|r|r}
\hline$\#$ & Resposta & $\%$ & Contagem \\
\hline 1 & Primeiro Grau Completo & $1.98 \%$ & 2 \\
\hline 2 & Primeiro Grau Incompleto & $0.00 \%$ & 0 \\
\hline 3 & Ensino Médio Completo & $7.92 \%$ & 8 \\
\hline 4 & Ensino Médio Incompleto & $5.94 \%$ & 6 \\
\hline 5 & Graduação Completo & $34.65 \%$ & 35 \\
\hline 6 & Graduação Incompleto & $19.80 \%$ & 20 \\
\hline 7 & Pós Graduação & $23.76 \%$ & 24 \\
\hline 8 & Mestrado & $3.96 \%$ & 4 \\
\hline 9 & Doutorado & $1.98 \%$ & 2 \\
\hline & Total & $100 \%$ & 101 \\
\hline
\end{tabular}


Q30 - Você estudou em:

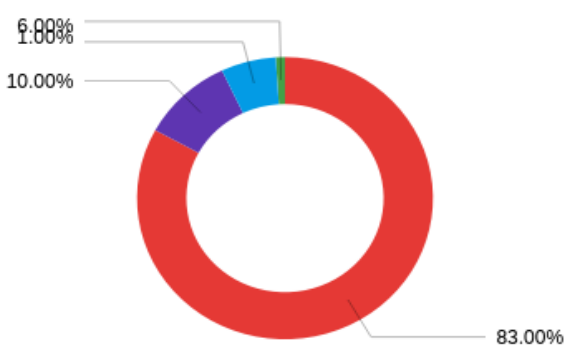

Escola Privada

Escola Pública

Outra instituiçāo de ensino

Nāo estudou em nenhuma instituição de ensino

\begin{tabular}{|r|r|r|r|r|r|r|r|}
\hline$\#$ & Field & Mínimo & Máximo & Média & $\begin{array}{r}\text { Desvio } \\
\text { padrão }\end{array}$ & Variância & Contagem \\
\hline 1 & $\begin{array}{r}\text { Você } \\
\text { estudou em: }\end{array}$ & 1.00 & 4.00 & 1.25 & 0.61 & 0.37 & 100 \\
\hline
\end{tabular}

\begin{tabular}{|l|r|r|r}
\hline$\#$ & Resposta & $\%$ & Contagem \\
\hline 1 & Escola Privada & $83.00 \%$ & 83 \\
\hline 2 & Escola Pública & $10.00 \%$ & 10 \\
\hline 3 & Outra instituição de ensino & $6.00 \%$ & 6 \\
\hline 4 & Não estudou em nenhuma instituição de ensino & $1.00 \%$ & 1 \\
\hline & Total & $100 \%$ & 100
\end{tabular}

Q31 - Ocupação atual:
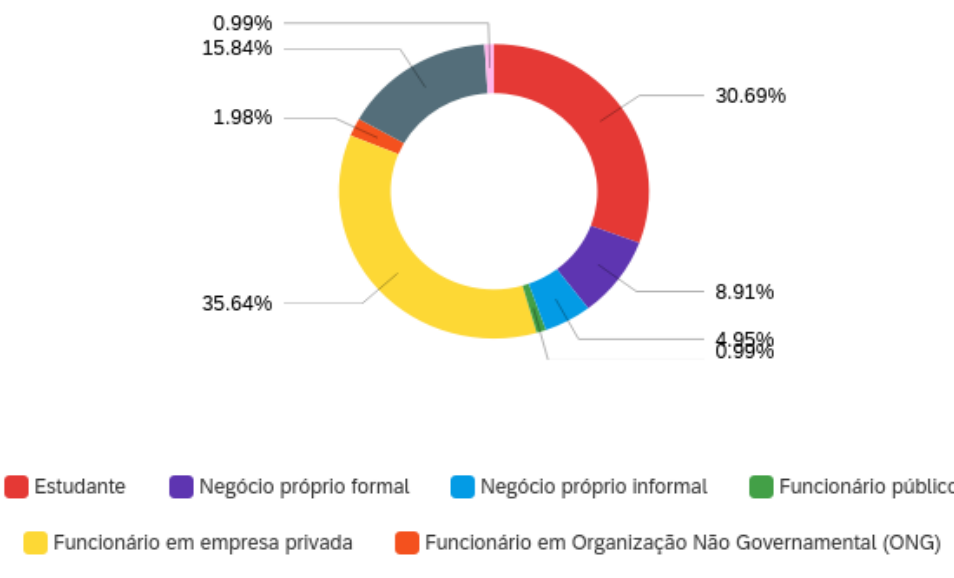

Nāo trabalha Outro 


\begin{tabular}{|r|r|r|r|r|r|r|r|} 
\# & Field & Mínimo & Máximo & Média & $\begin{array}{r}\text { Desvio } \\
\text { padrão }\end{array}$ & Variância & Contagem \\
\hline 1 & $\begin{array}{r}\text { Ocupação } \\
\text { atual: }\end{array}$ & 1.00 & 8.00 & 3.76 & 2.27 & 5.13 & 101 \\
\hline
\end{tabular}

\begin{tabular}{|c|c|c|c|}
\hline \# & Resposta & $\%$ & Contagem \\
\hline 1 & Estudante & $30.69 \%$ & 31 \\
\hline 2 & Negócio próprio formal & $8.91 \%$ & 9 \\
\hline 3 & Negócio próprio informal & $4.95 \%$ & 5 \\
\hline 4 & Funcionário público & $0.99 \%$ & 1 \\
\hline 5 & Funcionário em empresa privada & $35.64 \%$ & 36 \\
\hline 6 & $\begin{array}{l}\text { Funcionário em Organização Não Governamental } \\
\text { (ONG) }\end{array}$ & $1.98 \%$ & 2 \\
\hline 7 & Não trabalha & $15.84 \%$ & 16 \\
\hline 8 & Outro & $0.99 \%$ & 1 \\
\hline & Total & $100 \%$ & 101 \\
\hline
\end{tabular}

Q32 - Em qual região do Rio de Janeiro você mora?

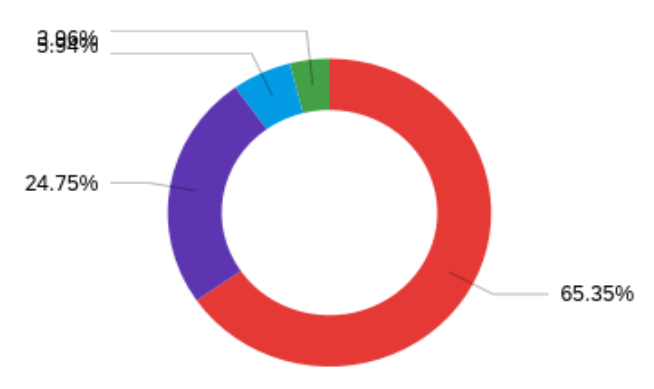

\begin{tabular}{|c|c|c|c|c|c|c|c|}
\hline \multirow[b]{2}{*}{ \# } & \multicolumn{2}{|r|}{ Zona Oeste } & Zona Sul & Zona Norte & \multicolumn{2}{|c|}{ Zona Central } & \\
\hline & Field & Mínimo & Máximo & Média & $\begin{array}{l}\text { Desvio } \\
\text { padrão }\end{array}$ & Variância & Contagem \\
\hline 1 & $\begin{array}{r}\text { Em qual região } \\
\text { do Rio de } \\
\text { Janeiro você } \\
\text { mora? }\end{array}$ & 1.00 & 4.00 & 1.49 & 0.78 & 0.61 & 101 \\
\hline
\end{tabular}




\begin{tabular}{|r|r|r|r|}
\hline$\#$ & Resposta & $\%$ & Contagem \\
\hline 1 & Zona Oeste & $65.35 \%$ & 66 \\
\hline 2 & Zona Sul & $24.75 \%$ & 25 \\
\hline 3 & Zona Norte & $5.94 \%$ & 6 \\
\hline 4 & Zona Central & $3.96 \%$ & 4 \\
\hline & Total & $100 \%$ & 101 \\
\hline
\end{tabular}

